\title{
Argonne
}

ANL/DIS-10-5

\section{Power Systems Simulations of the Western United States Region}

Projecting Water Withdrawals and Water Consumption for Thermal Power Generation in the WECC Region until 2025

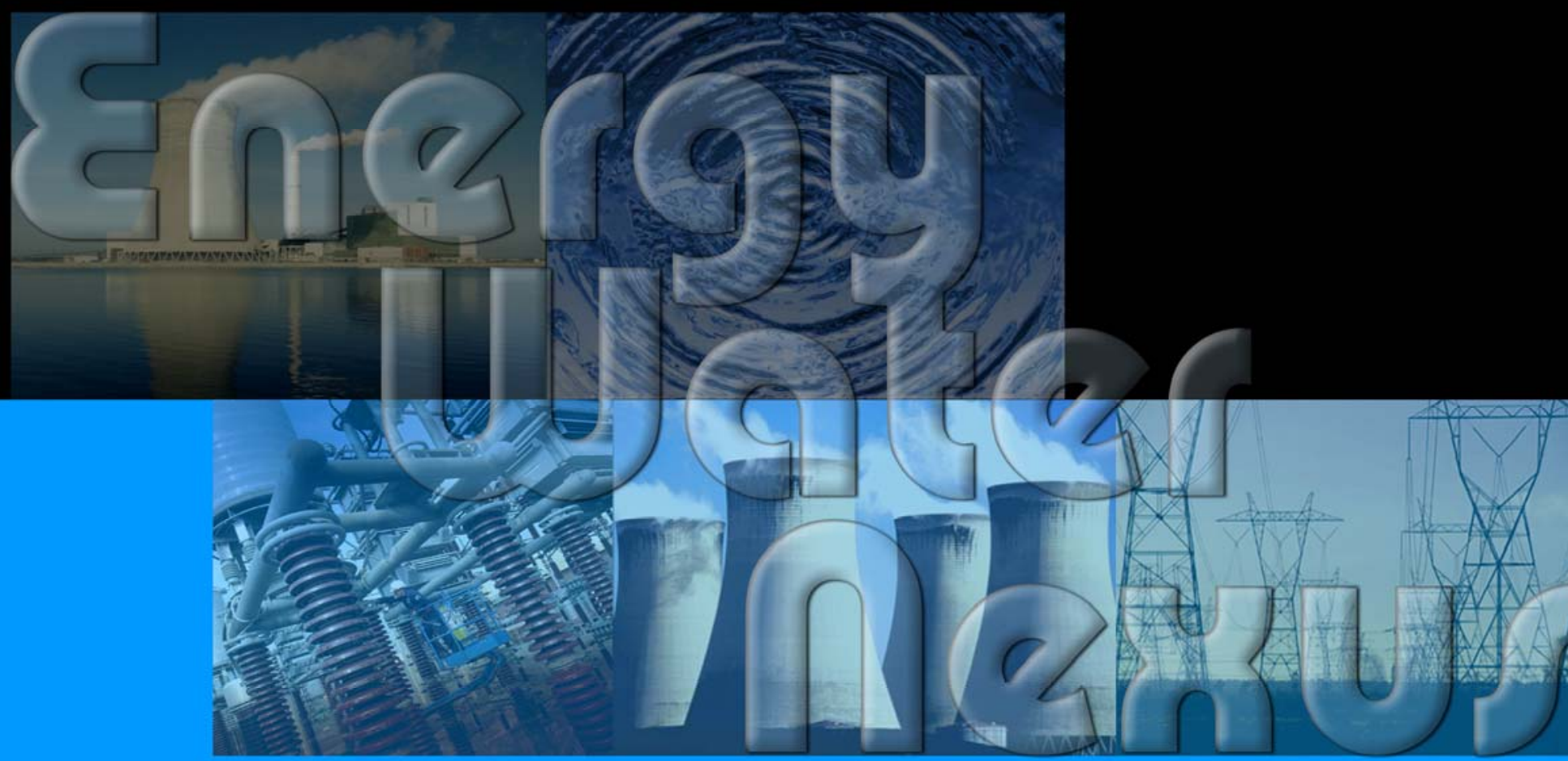


About Argonne National Laboratory

Argonne is a U.S. Department of Energy laboratory managed by UChicago Argonne, LLC under contract DE-AC02-06CH11357. The Laboratory's main facility is outside Chicago, at 9700 South Cass Avenue, Argonne, Illinois 60439. For information about Argonne and its pioneering science and technology programs, see www.anl.gov.

\section{Availability of This Report}

This report is available, at no cost, at http://www.osti.gov/bridge. It is also available

on paper to the U.S. Department of Energy and its contractors, for a processing fee, from:

U.S. Department of Energy

Office of Scientific and Technical Information

P.O. Box 62

Oak Ridge, TN 37831-0062

phone (865) 576-8401

fax (865) 576-5728

reports@adonis.osti.gov

\section{Disclaimer}

This report was prepared as an account of work sponsored by an agency of the United States Government. Neither the United States Government nor any agency thereof, nor UChicago Argonne, LLC, nor any of their employees or officers, makes any warranty, express or implied, or assumes any legal liability or responsibility for the accuracy, completeness, or usefulness of any information, apparatus, product, or process disclosed, or represents that its use would not infringe privately owned rights. Reference herein to any specific commercial product, process, or service by trade name, trademark, manufacturer, or otherwise, does not necessarily constitute or imply its endorsement, recommendation, or favoring by the United States Government or any agency thereof. The views and opinions of document authors expressed herein do not necessarily state or reflect those of the United States Government or any agency thereof, Argonne National Laboratory, or UChicago Argonne, LLC. 
ANL/DIS-10-5

\section{Power Systems Simulations of the Western United States Region}

Projecting Water Withdrawals and Water Consumption for Thermal Power Generation in the WECC Region until 2025

by

G. Conzelmann, V. Koritarov, L. Poch, P. Thimmapuram, and T. Veselka

Center for Energy, Environmental, and Economic Systems Analysis, Decision and Information Sciences Division Argonne National Laboratory, Argonne, Illinois

February 2010 



\section{NOTATION}

\section{Acronyms}

\begin{tabular}{|c|c|}
\hline $\mathrm{AEO}$ & Annual Energy Outlook \\
\hline AZNM & Arizona-New Mexico-Southern Nevada Power Area \\
\hline CAL & California \\
\hline EIA & Energy Information Administration \\
\hline EMCAS & Electricity Market Complex Adaptive System \\
\hline EMM & Electricity Market Module \\
\hline FERC & Federal Energy Regulatory Commission \\
\hline GADS & Generator Availability Data Set \\
\hline LDC & load duration curve \\
\hline NEMS & National Energy Modeling System \\
\hline NERC & North American Electric Reliability Corporation \\
\hline NETL & National Energy Technology Laboratory \\
\hline NWPP & Northwest Power Pool \\
\hline $\mathrm{O} \& \mathrm{M}$ & operation and maintenance \\
\hline RMPA & Rocky Mountain Power Area \\
\hline WECC & Western Electricity Coordinating Council \\
\hline
\end{tabular}

\section{Units of Measure}

BGY billion gallons per year

GW gigawatt(s)

MWh megawatt-hour(s)

TWh terawatt-hour(s) 
This page intentionally blank 


\section{CONTENTS}

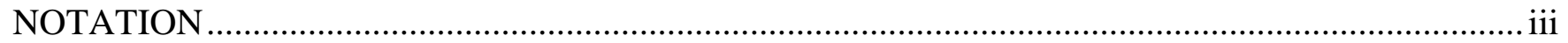

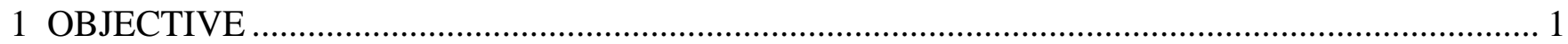

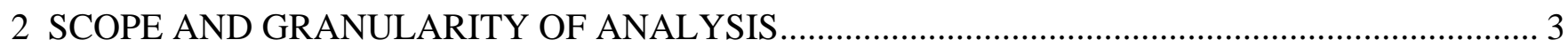

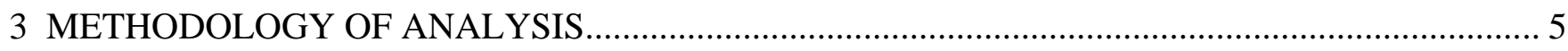

3.1 Data Collection and Preparation ............................................................................................ 5

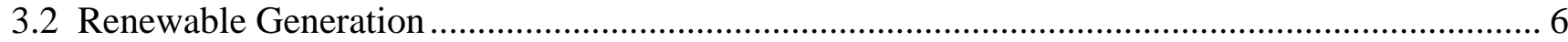

3.3 Current Loads and Load Forecast .......................................................................................... 7

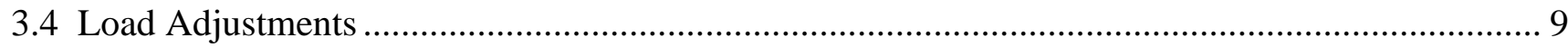

3.5 Capacity Expansion Modeling................................................................................................. 9

3.6 Thermal Dispatch Modeling ……………………................................................................ 12

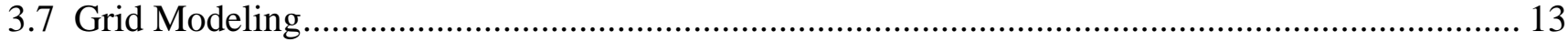

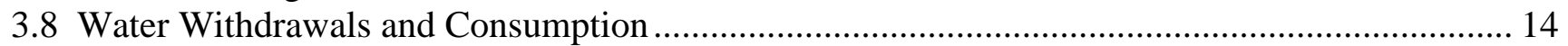

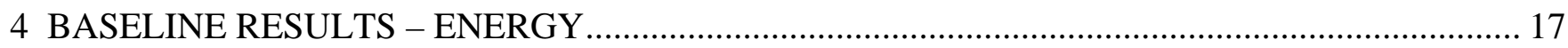

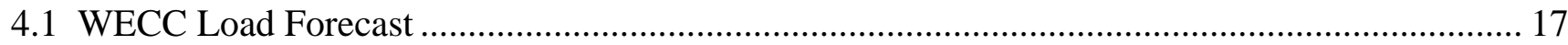

4.2 WECC Capacity and Generation Projections ............................................................................. 17

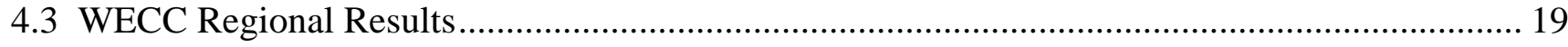

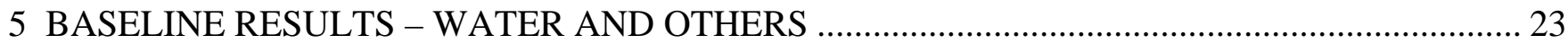

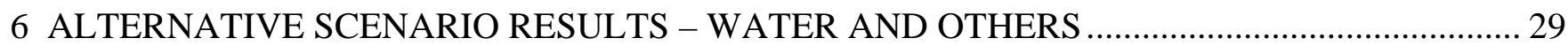

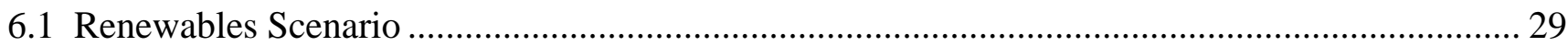

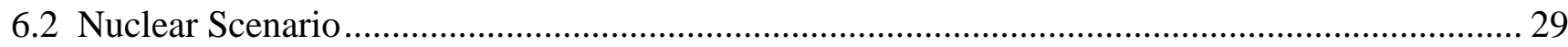

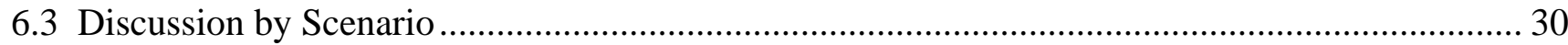

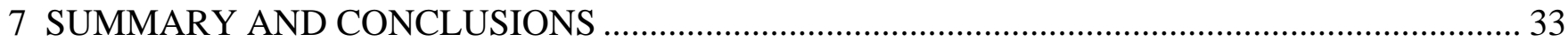

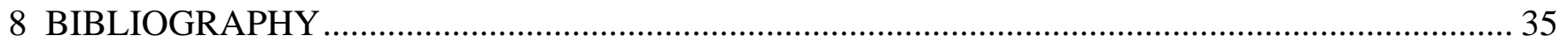

\section{FIGURES}

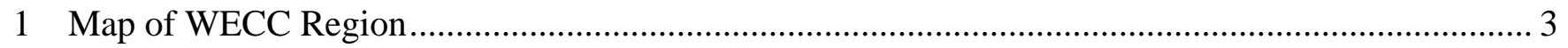

2 Example for Hydro Variability - Natural Flow Colorado River at Lees Ferry ….................................. 3

3 WECC Wind Generation, 2005 and 2025................................................................................... 7

4 Hydropower Plant Operations.................................................................................................... 7

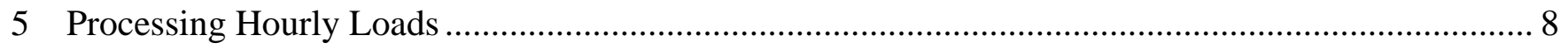




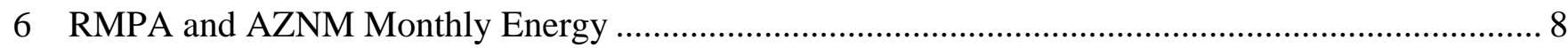

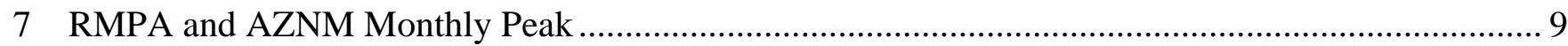

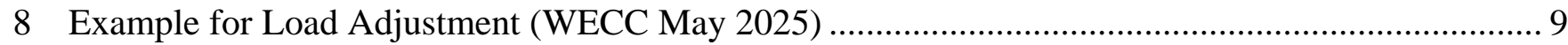

9 Example for Load Duration Curves (WECC May 2025) ........................................................ 10

10 AEO (EIA 2006a) Electricity Market Model Supply Regions ................................................... 10

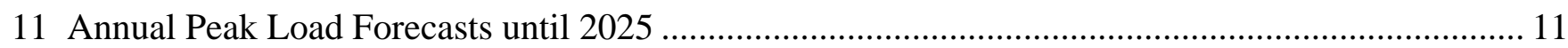

12 Generating Technologies Represented in the Electricity Market Module...................................... 11

13 Screening Curves of Selected Candidate Technologies............................................................. 12

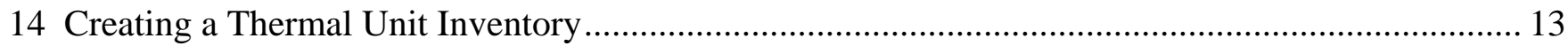

15 Example for Results of Maintenance Scheduling Routine ...................................................... 13

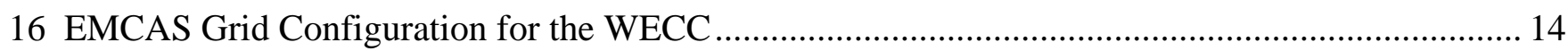

17 Projected Baseline WECC Capacity and Load Balance ............................................................ 17

18 Projected Baseline WECC Installed Capacity and Electricity Generation by Technology............... 17

19 Projected Baseline WECC New Capacity Additions by Technology ......................................... 18

20 Projected Baseline WECC Renewable Capacity and Electricity Generation by Technology........... 18

21 Projected Baseline Capacity and Load Balance by Main WECC Region .................................... 19

22 Projected Baseline Generating Capacity by Technology and Main WECC Region ........................ 19

23 Projected Baseline Electricity Generation by Technology and Main WECC Region...................... 20

24 Projected Baseline New Capacity Additions by Technology and Main WECC Region................... 20

25 Projected Baseline Renewable Capacity by Technology and Main WECC Region ........................ 20

26 Projected Baseline Renewable Electricity Generation by Technology and Main WECC Region ..... 21

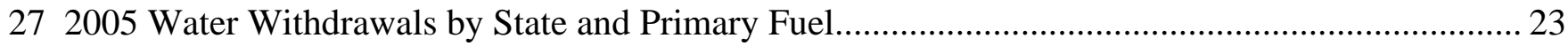

28 Water Consumption by State and Primary Fuel ................................................................ 23 
292005 Water Withdrawals and Consumption by State

302005 Electricity Generation by State and Primary Fuel 24

312005 Cooling Technology by State and Primary Fuel.............................................................. 25

322005 Water Withdrawals for Thermal Power Generation by County …....................................... 27

332005 Water Consumption for Thermal Power Generation by County ......................................... 27

34 Projected Baseline Water Withdrawals by Primary Fuel ....................................................... 28

35 Projected Baseline Water Consumption by Primary Fuel …................................................... 28

362005 Power Sector $\mathrm{CO}_{2}$ Emissions by State and Primary Fuel ............................................... 28

37 Projected Baseline Power Sector $\mathrm{CO}_{2}$ Emissions by Primary Fuel ............................................ 28

38 Projected New Capacity Additions by Scenario and Technology ................................................ 30

39 Projected Water Withdrawals and Withdrawal Intensity by Scenario......................................... 30

40 Projected Water Consumption and Consumption Intensity by Scenario...................................... 31

41 Projected $\mathrm{CO}_{2}$ Emissions and Emission Intensity by Scenario ................................................ 31

42 Projected Water Withdrawals, Water Consumption, and $\mathrm{CO}_{2}$ Emissions by Scenario.................... 32 
This page intentionally blank 


\section{OBJECTIVE}

This report documents a part of a broad assessment of energy-water-related issues in the western United States. The full analysis involved three Department of Energy national laboratories: Argonne National Laboratory, Los Alamos National Laboratory, and Sandia National Laboratories. Argonne's objective in the overall project was to develop a regional power sector expansion forecast and a detailed unit-level operational (dispatch) analysis. With these two major analysis components, Argonne estimated current and future freshwater withdrawals and consumption related to the operation of U.S. thermal-electric power plants in the Western Electricity Coordinating Council (WECC) region for the period 2005-2025. Water is withdrawn and used primarily for cooling but also for environmental control, such as sulfur scrubbers. The current scope of the analysis included three scenarios:

1. Baseline scenario as a benchmark for assessing the adequacy and cost-effectiveness of water conservation options and strategies,

2. High nuclear scenario, and

3. High renewables scenario.

Baseline projections are consistent with forecasts made by the WECC and the Energy Information Administration (EIA) in its Annual Energy Outlook (AEO) (EIA 2006a). Water conservation scenarios are currently limited to two development alternatives that focus heavily on constructing new generating facilities with zero water consumption. These technologies include wind farms and nuclear power plants with dry cooling. Additional water conservation scenarios and estimates of water use associated with fuel or resource extraction and processing will be developed in follow-on analyses. 
This page intentionally blank 


\section{SCOPE AND GRANULARITY OF ANALYSIS}

Water withdrawals and consumption are estimated for current and future operations of thermal power plants in the western United States, with a near-term focus on the portion of the WECC (see Figure 1) that is within the United States. The WECC subregions modeled include the Northwest Power Pool (NWPP), Rocky Mountain Power Area (RMPA), Arizona-New Mexico-Southern Nevada Power Area (AZNM), and California (CAL). Special attention is paid to interdependencies between hydropower and thermal power plant operations, as hydropower plants may serve up to $40 \%$ of the WECC load in wet hydrology years. In some water basins, such as the Colorado River system, annual hydropower generation can vary by more than a factor of 5 (see Figure 2). Hydrology conditions impact the dispatch of the thermal system and therefore water use by the power sector. A drought in the region not only reduces the water available for hydropower generation, but also increases the water consumption from thermal generation, as the system needs to rely more on thermal power to serve load.

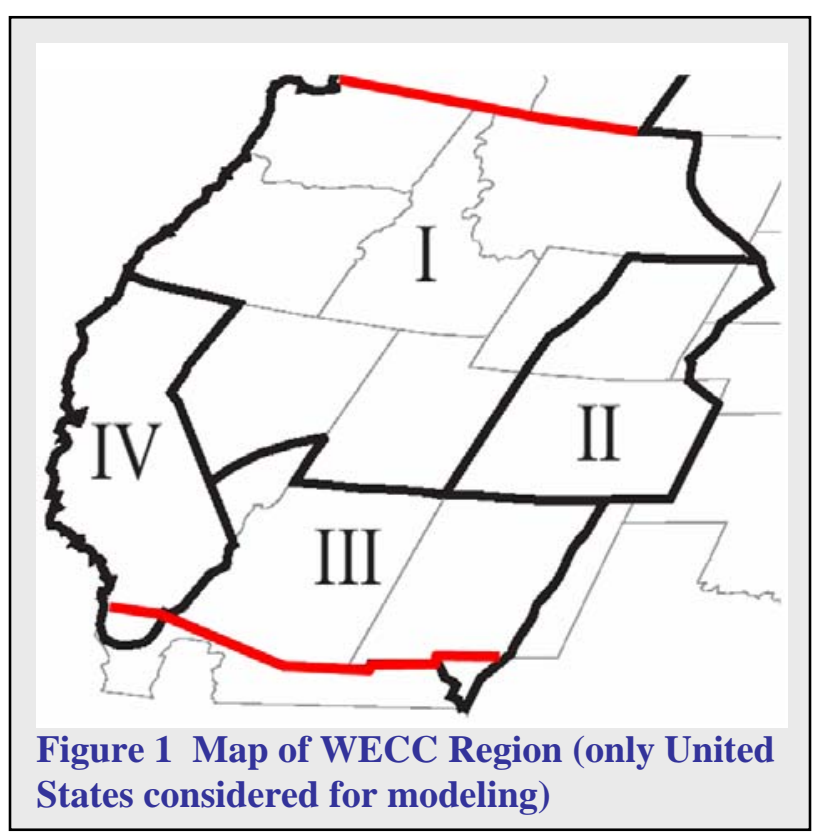

Hydropower plant generation is determined on an hourly time step. In the current model implementation, hydro is simulated as an aggregate generation resource that serves both base load and peaking duties. The information for the aggregation is compiled from individual plant-level data. The hourly dispatch of the aggregate power plant is based on monthly generation control totals, the amount of water used for base load duties, estimated monthly hydropower capability, and a WECC-wide hourly load profile.

Thermal power plants are simulated at the unit level. A monthly probabilistic dispatch model is used to simulate thermal power plant

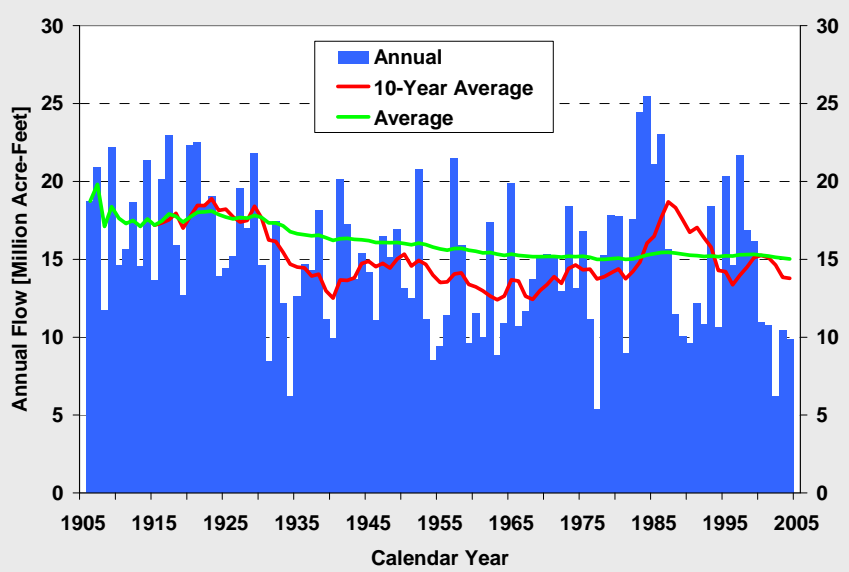

Figure 2 Example for Hydro Variability - Natural Flow Colorado River at Lees Ferry production to meet load that is not served by hydropower plants and other renewable resources, such a wind power. Load is represented as monthly load duration curves (LDCs). Through this process, monthly average capacity factors, generation levels, and water consumption and water use estimates are obtained at the unit level. Maintenance and random forced outages are accounted for at the unit level. 
For electricity demand, a WECC-wide hourly electricity demand profile is constructed for the period 2005-2025 from control area load profiles in combination with 10-year WECC forecasts and 2025 forecasts from the AEO. 


\section{METHODOLOGY OF ANALYSIS}

The WECC-US system is modeled dynamically for the period 2005-2025 by using several modeling tools. The methodology employs the following sequence of operations:

1. Collect and process data and information.

2. Determine hourly renewable generation, including dispatchable and non-dispatchable aggregate hydropower and other non-dispatchable plants, such as wind.

3. Determine current hourly electricity loads and forecast future load levels.

4. Adjust loads for non-dispatchable renewable generation and hydropower plant generation.

5. Develop baseline capacity expansion plan until 2025.

6. Run a probabilistic thermal dispatch model to estimate electricity generation by thermal generation units from the period 2005-2025.

7. Compute thermal power plant water withdrawals and consumption.

8. Develop alternative capacity expansion scenarios until 2025.

9. Run probabilistic dispatch model for all future years to project generation and water withdrawals and water use until 2025.

10. Summarize results.

Refinements in future follow-on studies will include uncertainty analyses, particularly with regard to the stochastic nature of water inflows.

\subsection{Data Collection and Preparation}

The baseline analysis utilizes an extensive set of information. The underlying data are compiled from various sources, with considerable effort spent on data validation to ensure data consistency. The following is a list of information sources used to compile a WECC-wide unit inventory, hourly load profiles, load projections, fuel price projections, technology data, and grid topology.

\section{Inventory of Existing and Proposed Power Plants}

- Form EIA-860 (Annual Electric Generator Report) (EIA 2006d)

- Identifies the generator location

- Identifies the generator ownership

- Provides information on summer and winter generating capability

- Identifies the type of primary mover

- Identifies the fuel type(s) used by the generator

- Identifies the source(s) of water used by the generator

- Form EIA-767 (Steam-Electric Plant Operation and Design Report) (EIA 2007)

- Identifies the type of pollution control device(s) installed at the generator location

- Identifies the type of cooling equipment used by the generator

- Provides information on water usage for cooling and pollution control

- FERC Form-423 (Monthly Report of Cost and Quality of Fuels for Electric Plants) and Form EIA-423 (Monthly Cost and Quality of Fuels for Electric Plants Data)

- Provides information on the price of the fuel(s) used by generator

- Provides information on the sources of the fuel(s) used by the generator 
- Provides information on the quality of the fuel(s) used by the generator (e.g., sulfur content, ash content, and higher heating value)

- FERC Form-423 contains data from plants owned by electric utilities

- EIA-423, which began in 2002, contains data from plants owned by independent power producers and combined heat and power producers

- Form EIA-906 (Power Plant Report) (EIA undated)

- Provides information on monthly fuel consumption by generator

- Provides information on monthly generation levels by generator

- NERC Generator Availability Data Set (GADS) (NERC 2009)

- Identifies scheduled maintenance outage rates by type of technology

- Provides outages by type of technology

\section{Historical Load Data}

- $\quad$ Form FERC-714 (FERC 2006)

- Provides information on hourly load data by control area

\section{Load Projections}

- WECC near-term forecast (Loads and Resources Report and Form FERC-714) (FERC 2006)

- Provides information on monthly loads for 2 years into the future

- Provides information on seasonal loads for 3- to 10-year forecast period

- EIA AEO (EIA 2006a)

- Provides annual projections until 2030

\section{Fuel Price Projections}

- $\quad$ EIA AEO (EIA 2006a) projections

- Provides annual fuel price escalations by fuel type until 2030

\section{Expansion Candidate Technology Data}

- EIA AEO 2006 (EIA 2006a)

- Provides information on technical and economic performance parameters of representative power generation technologies

- National Energy Technology Laboratory (NETL) (NETL 2006, 2007)

- Provides information on water withdrawal and consumption for typical power generation technologies used for power system expansion

\section{Grid topology}

- $\quad$ WECC 2006 Power Supply Assessment (WECC 2006b)

- Provides information on zone topology and total transfer capabilities for power between zones

\subsection{Renewable Generation}

Non-dispatchable renewable generation is estimated first. The detailed output tables for the AEO 2006 reference case provide the annual energy generation until 2025 by renewable technology for the three WECC regions used by EIA (EIA combines AZNM and RMPA into one region RMPA-AZ). 
Geothermal, municipal solid waste, and wood and biomass combustion units are included in the dispatch model. For wind, eight available wind generation patterns are used for the western United States and are assigned as representative wind patterns to each of the three EIA areas to obtain hourly wind generation patterns for each WECC sub-region. A scaling routine is used to match the AEO regional wind energy totals and sum across the regions to obtain a WECC-wide hourly wind generation trace until 2025 (see Figure 3 for WECC wind generation in 2005 and 2025). Wind generation is then subtracted from the total WECC load (see load discussion below for more details). A similar load subtraction is performed for nondispatchable hydropower, that is, run-of-river power plants.

To model the hourly generation pattern from dispatchable hydropower plants (plants with reservoirs or storage capabilities), a peak shaving approach is used. Information from EIA-906 is used to estimate monthly hydropower generation patterns for individual hydropower plants. Also, data from various sources are used to separate power plant capabilities obtained from EIA-860 into baseload and peaking duties. Total hydropower monthly generation levels and plant capabilities are then computed. Next, the hourly

hydropower dispatch is simulated by using a peak shaving algorithm that minimizes the peak load that the thermal system must serve subject to monthly hydropower capacity and energy constraints, spinning reserve duties, hourly ramping constraints, and daily change limitations (Figure 4).

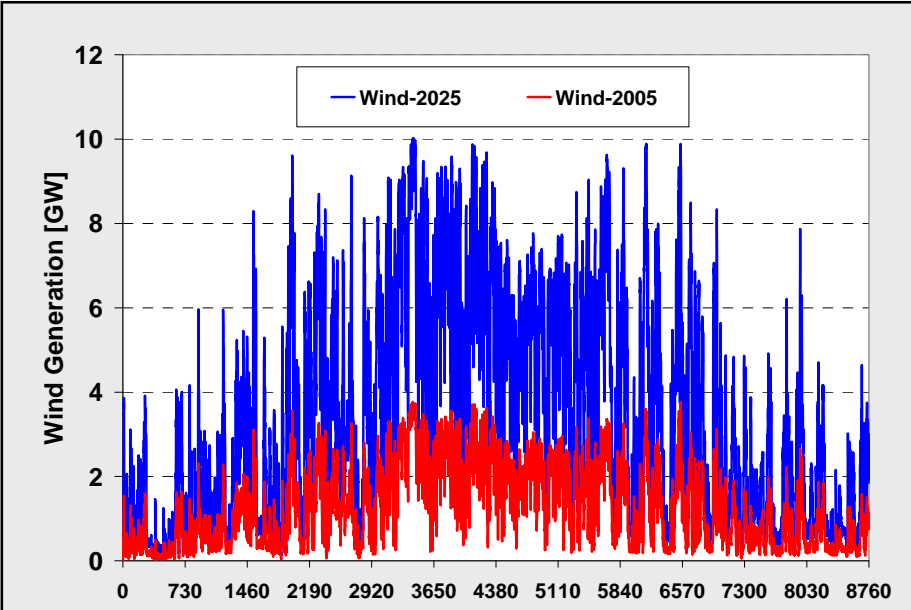

Figure 3 WECC Wind Generation, 2005 and 2025

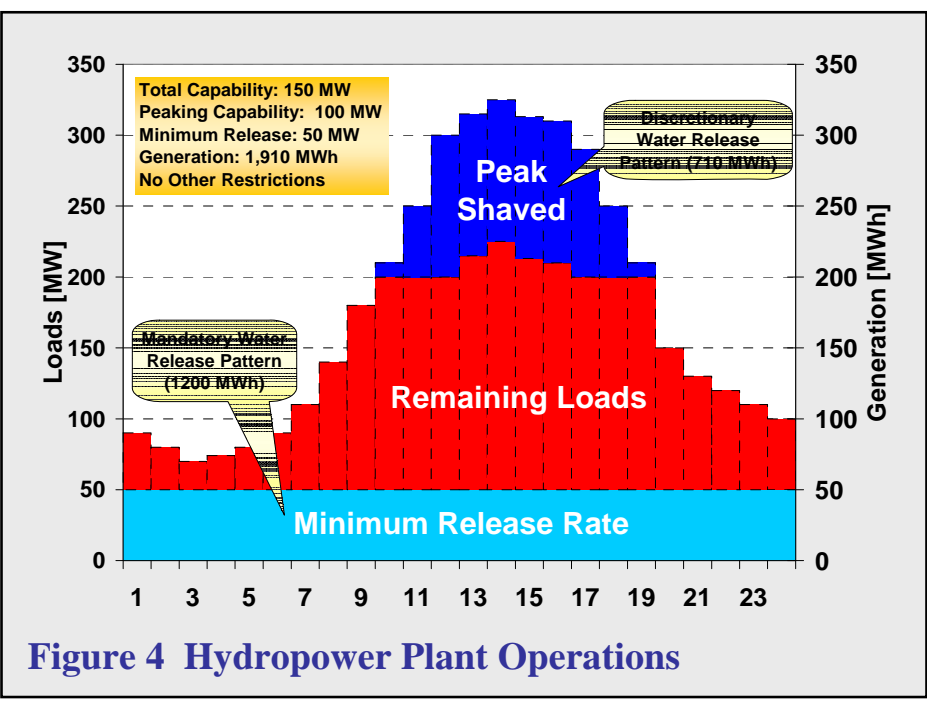

\subsection{Current Loads and Load Forecast}

Figure 5 shows the process used in developing the hourly load data for the analysis period 2005-2025. Hourly historical load data are assembled by control area, separated into individual power pools, and aggregated into the four major WECC areas (i.e., NWPP, RMPA, AZNM, and CAL). The areas only cover U.S. territory. 


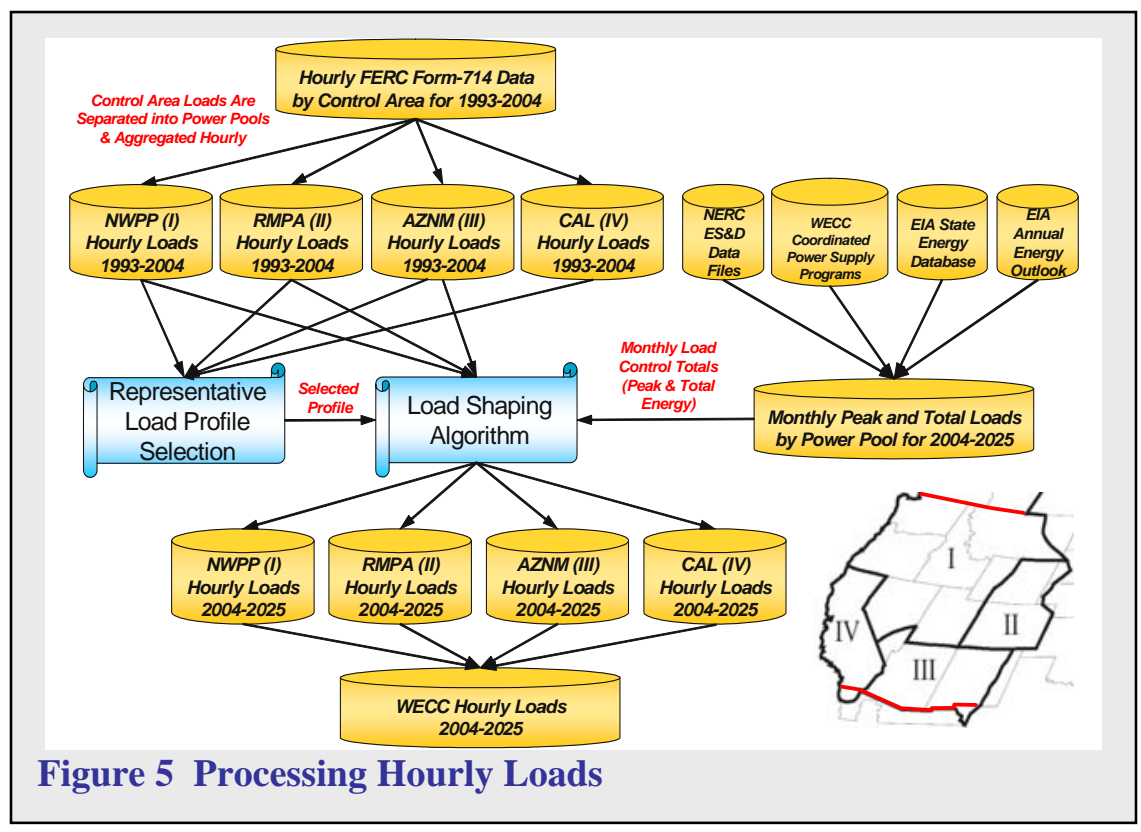

Figures 6 and 7 show relative monthly energy factors and monthly relative peak fractions based on FERC-714 for two of the major areas (RMPA and AZNM) for a selection of historic years. From this data set for each major area, the representative load profile is selected for the data set with the lowest sum of squared differences relative to the average profile. This representative profile is used as the basis for constructing hourly load projections for future years through 2025. A scaling algorithm is then used to adjust the representative hourly load profiles to match peak and total load targets that come from various statistics, including WECC's coordinated power supply programs, EIA state energy databases, AEO (EIA 2006a), and electricity supply and demand data from the North American Electric Reliability Corporation (NERC).
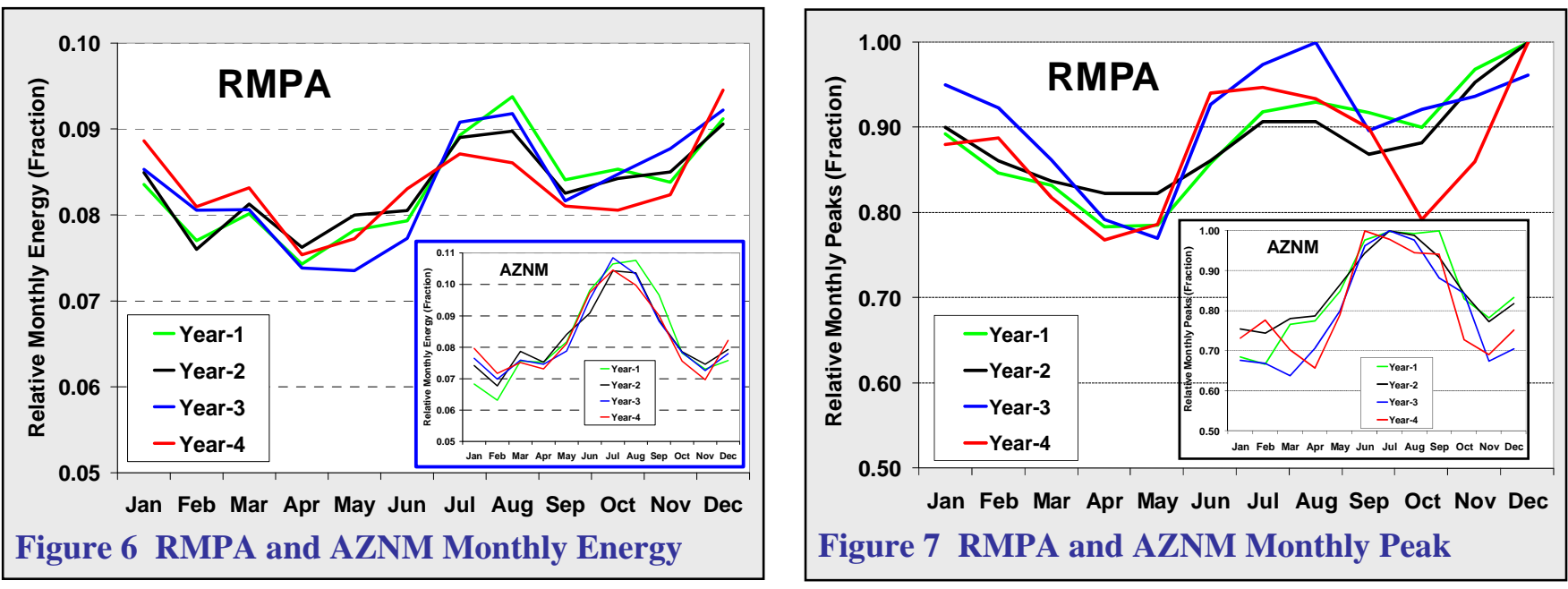


\subsection{Load Adjustments}

As discussed above, the original hourly total WECC load data series are adjusted in two ways:

1. For non-dispatchable resources (wind, run-of-river hydro, etc.) by load subtraction, and

2. For dispatchable hydropower using the peak shaving algorithm.

The remaining adjusted hourly loads are used to construct monthly LDCs that are served by the thermal system and are input into the probabilistic thermal dispatch model for the simulations. Figure 8 shows a 1-week example of how the load adjustments affect the total load served by the thermal system. Figure 9 shows the monthly load duration curves.
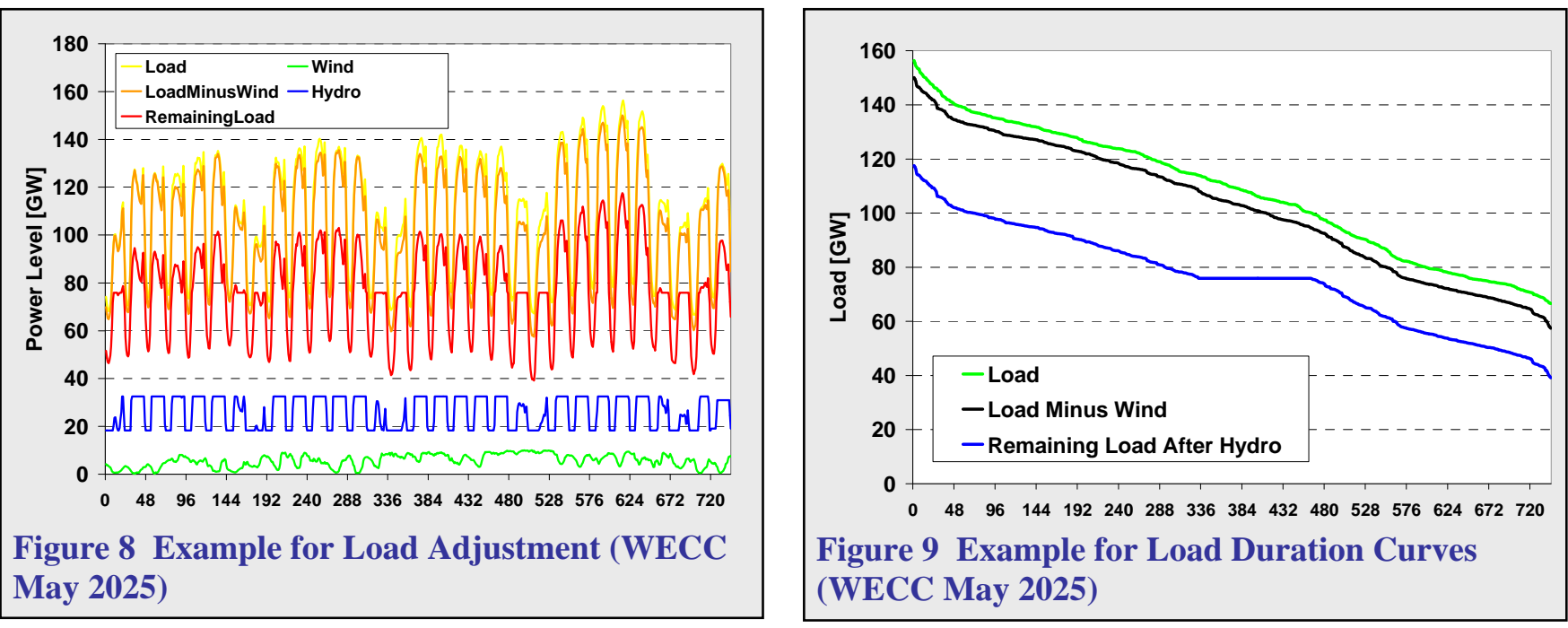

\subsection{Capacity Expansion Modeling}

The baseline capacity expansion scenario for the WECC system until 2025 was developed by using the AEO (EIA 2006a) as a starting point. These projections are derived using the National Energy Modeling System (NEMS) Electricity Market Module (EMM). On the basis of the fuel prices and electricity demands provided by other modules of the NEMS, the EMM determines the most economic way to supply electricity, subject to environmental and operational constraints. A detailed description of the EMM is available in the EIA publication, Electricity Market Module of the National Energy Modeling System 2006 (EIA 2006b).

The AEO 2006 contains projections of new capacity additions by technology for a total of 13 NERC regions and sub-regions (see Figure 10).

Three of these regions represent a geographic area in the United States served by the WECC:

- Region 11: Northwest Power Pool

- Region 12: Rocky Mountain Power Area, Arizona, New Mexico, and Southern Nevada

- Region 13: California 
The WECC defines four general load areas or regions within its service territory:

1. Northwest Power Pool Area

2. Rocky Mountain Power Area

3. Arizona - New Mexico - Southern Nevada Power Area

4. California - Mexico Power Area

To maintain consistency with the AEO (2006a), this analysis also used a representation of the WECC system with three regions for the development of the revised capacity expansion plan.

For the Energy-Water Nexus project, the AEO (2006a) electricity demand projections for WECC regions were updated with the

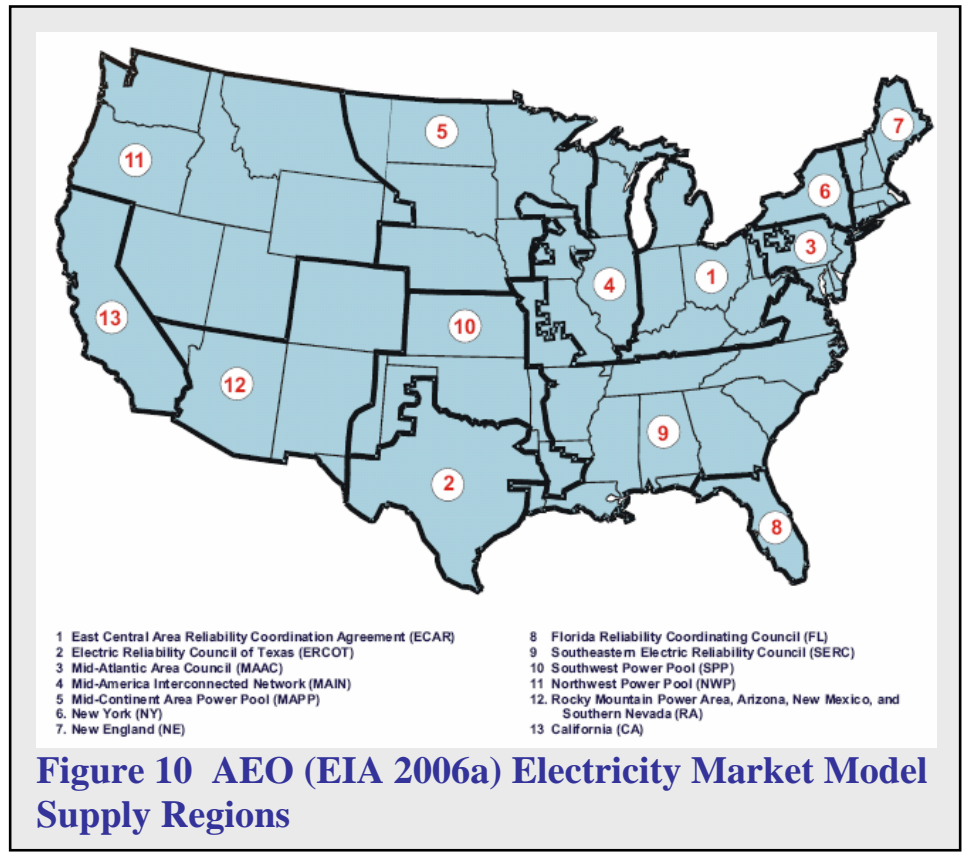
latest WECC demand projections. The Summary of Estimated Loads and Resources report (WECC 2006a) was used to update the AEO (2006a) demand projections for the WECC regions. The revised peak load forecasts for each of the WECC regions are shown in Figure 11. These revised load forecasts were used to determine the needs for additional capacity until 2025.

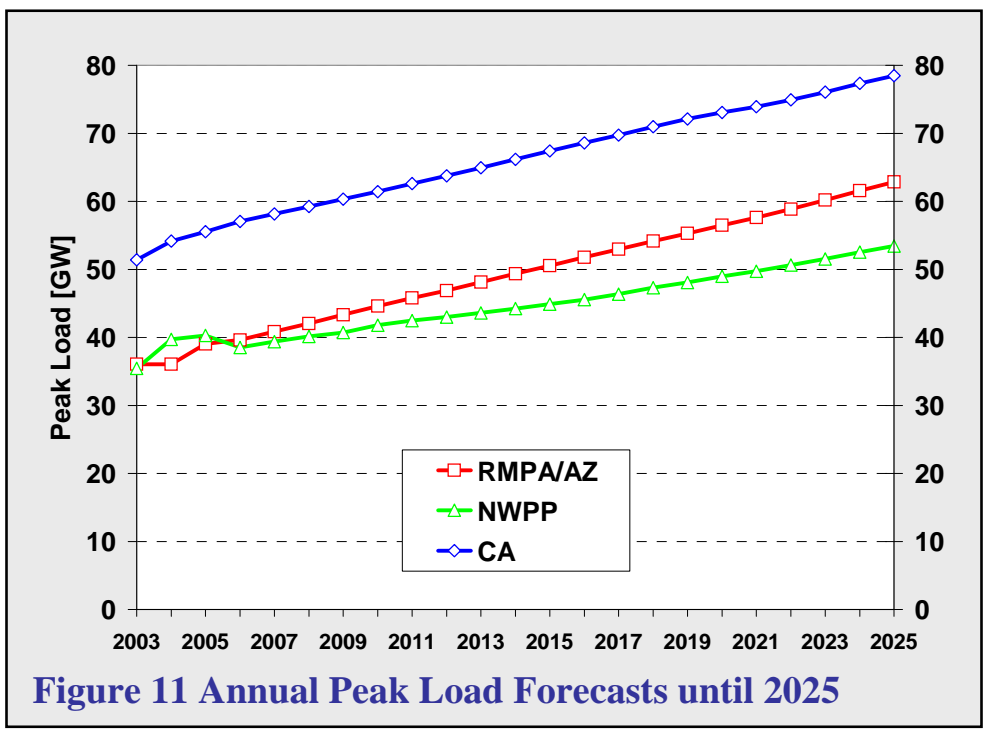

The EMM analysis for the AEO (EIA 2006a) has considered a number of different candidate generating technologies. As shown in Figure 12, they include both conventional and renewable technologies. The EMM analysis also allowed for the change and improvement of technical and economic parameters over time (i.e., learning parameters). 


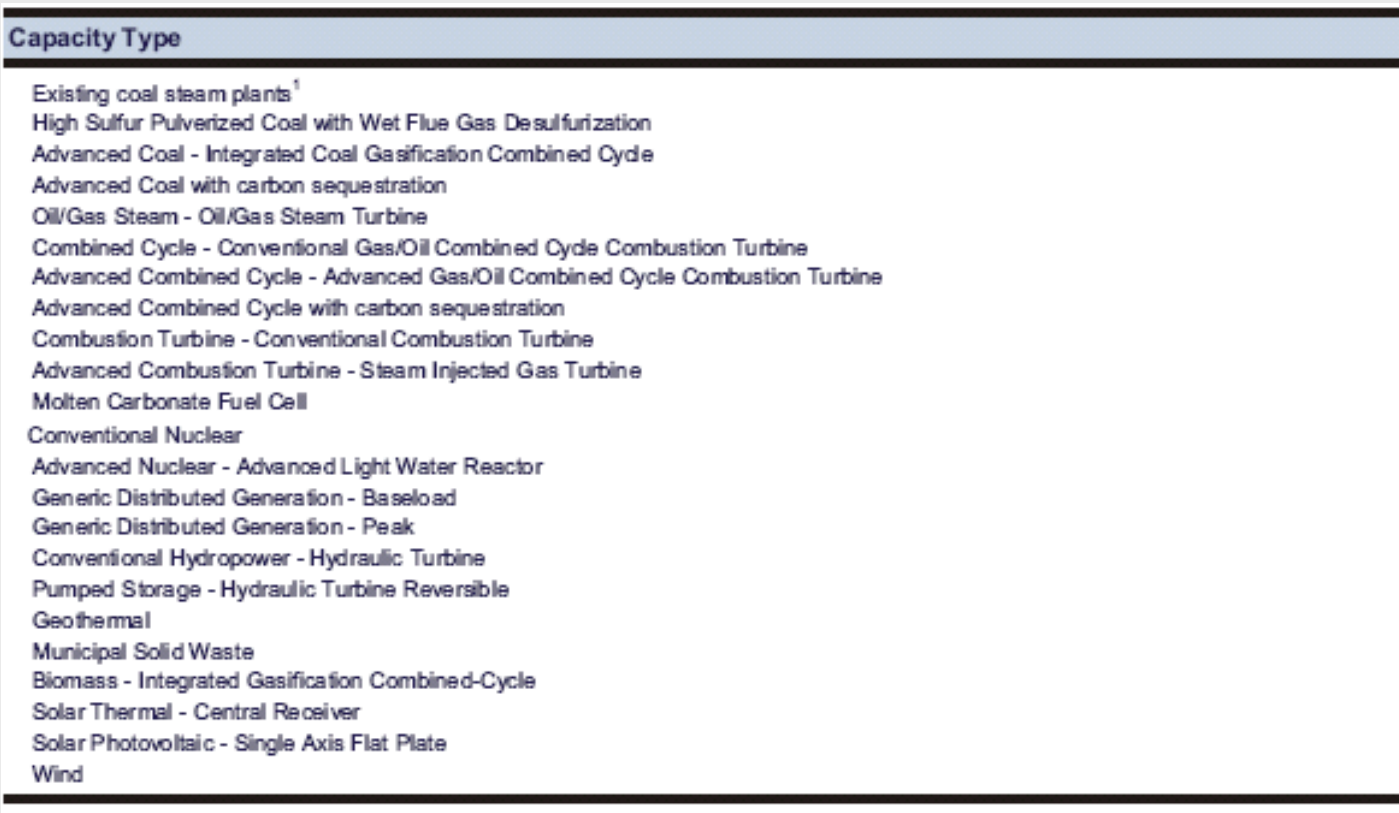

'The EMM represents 32 different types of existing coal steam plants, based on the different possible configuration of Nox, particulate and $\mathrm{SO}_{2}$ emission control devices, as well as future options for controlling mercury.

Source: Energy Information Administration, Office of Integrated Analysis and Forecasting.

Figure 12 Generating Technologies Represented in the Electricity Market Module (EIA 2006c)

By using the data provided in AEO (EIA 2006a), a set of screening curves was constructed for selected generating technologies to illustrate their relative economic competitiveness for future system expansion (Figure 13). The screening curve analysis is frequently used to examine the basic economic competitiveness of different generating technologies. The approach consists of calculating the annualized cost of electricity generation as a function of unit utilization level (capacity factor). The screening curves for several technology options can be plotted on the same graph to determine which options are the most economic at different utilization levels. (The screening curve analysis is an approximate method and is not a substitute for a thorough analysis.) One of the limitations of the screening curve analysis is that it does not consider many important technical and economic characteristics of generating technologies, as well as their operation and potential role in the power system.

On the basis of the revised demand forecast for WECC regions, a planning reserve margin of 15\% was used as a driver for new capacity additions until 2025. As stated in WECC (2006a), the capacity needs are determined at the level of WECC regions, and each region needs to maintain a minimum planning reserve margin of $15 \%$. Therefore, the total capacity additions for the WECC system are obtained as the sum of new capacity additions in each of the regions. 


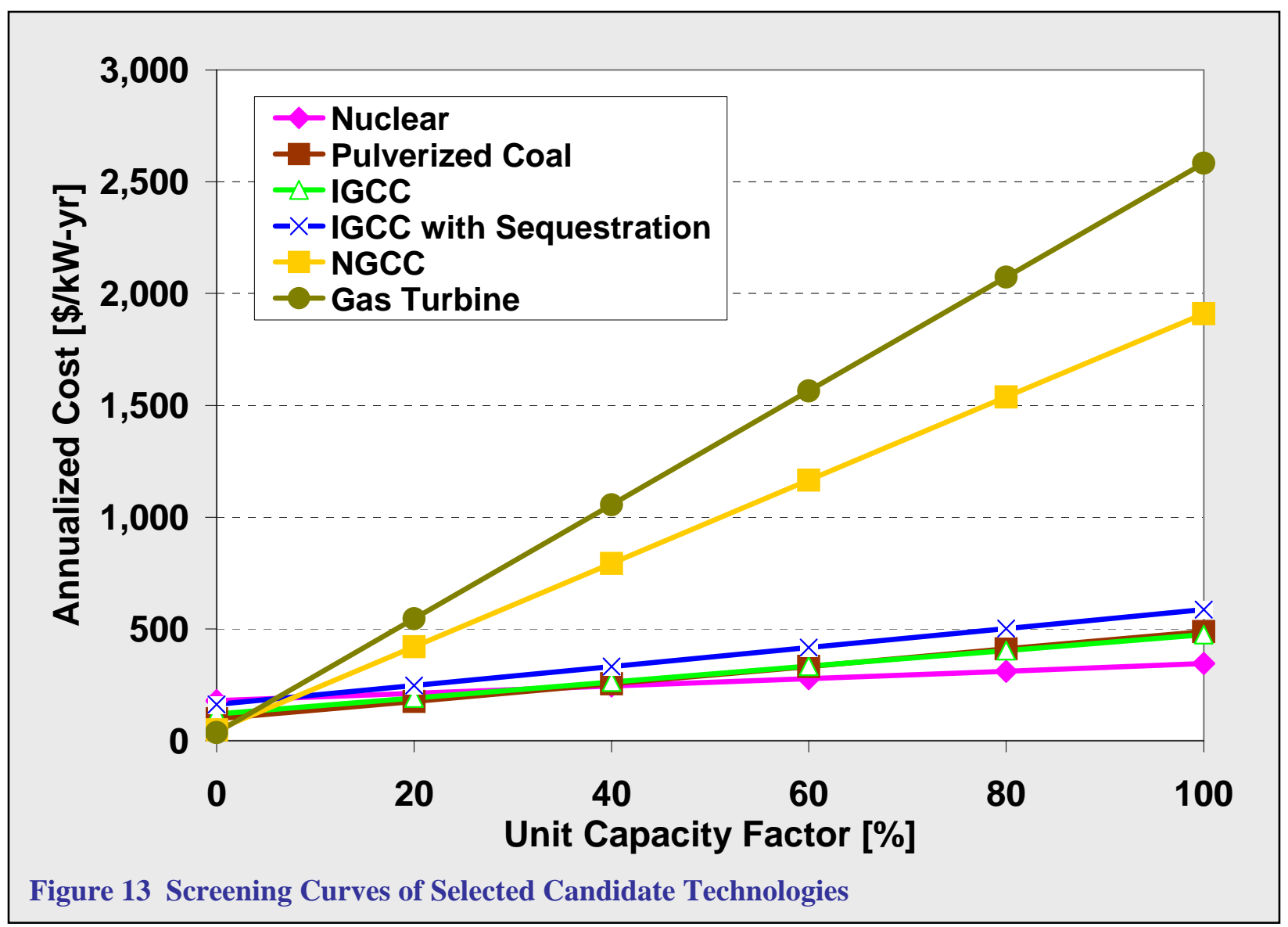

The technology mix of new generating capacity until 2025 was based on the AEO (EIA 2006a) projections for each WECC region. Compared to the AEO (EIA 2006a) expansion plan, the revised load forecasts and the $15 \%$ planning reserve margin requirement did not produce any changes in the capacity needs for the NWPP region, while they resulted in slightly increased capacity needs for the RMPA/AZ and California regions. The additional generating capacity in these two regions was needed in later years, from approximately 2015-2025. Again, it was assumed that the technology mix for this additional capacity would correspond to that of the AEO (EIA 2006a).

\subsection{Thermal Dispatch Modeling}

The first step in the dispatch modeling is to create a validated unit inventory for the entire WECC region. As shown in Figure 14, EIA-860 is used as a starting point, EIA-423FERC Form 423 to add fuel data to the inventory, EIA-906 to obtain estimates for heat rates, EIA-767 for water use and pollution control data, the GADS database on outage information, and the AEO (EIA 2006a) tables for variable operation and maintenance (O\&M) costs.

With the complete unit inventory, a unit-level hourly thermal probabilistic dispatch model is run that accounts for forced outages and scheduled maintenance. Future maintenance schedules are estimated with a routine that maximizes the minimum reserve margin. Figure 15 shows sample results for the maintenance scheduler in combination with a forced outage scenario. The dispatch model utilizes a 
convolution process in which the loads that a unit serves include the original LDC plus loads that could not be served by units loaded earlier due to forced outages.

From the dispatch routine, unit-level hourly generations and associated water consumption are obtained and then summarized for each simulation month. Hydropower plants in this initial analysis are modeled as an aggregate generation resource that serves base load and peaking duties.

The hourly dispatch of the aggregate power plant is based on monthly generation control totals, the amount of water used for base load duties, estimated monthly hydropower capability, and a WECC-wide hourly load profile.

\subsection{Grid Modeling}

Due to schedule and funding constraints, the current dispatch modeling does not take into account any potential transmission constraints. However, Argonne has a detailed electricity market analysis tool - the Electricity Market Complex Adaptive System (EMCAS) - that is capable of multi-year dispatch simulations of detailed transmission grid configurations. Figure 16 shows an initial implementation for the entire WECC region (including Canada and Mexico). This configuration is similar to the grid representations WECC uses for its power supply assessments and is based on aggregate demands and total transfer capabilities among regions.
Figure 14 Creating a Thermal Unit Inventory
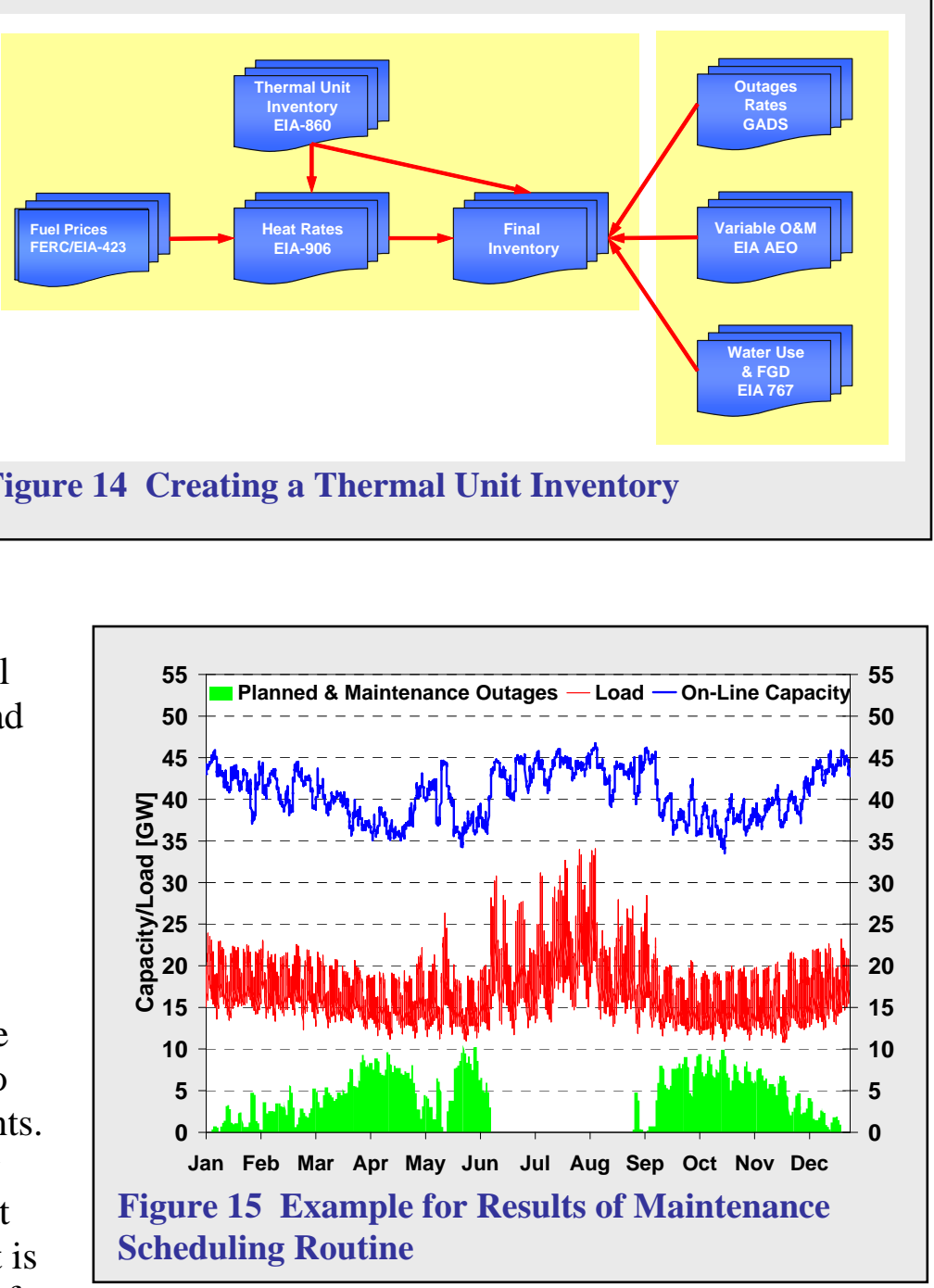

Figure 15 Example for Results of Maintenance Scheduling Routine 


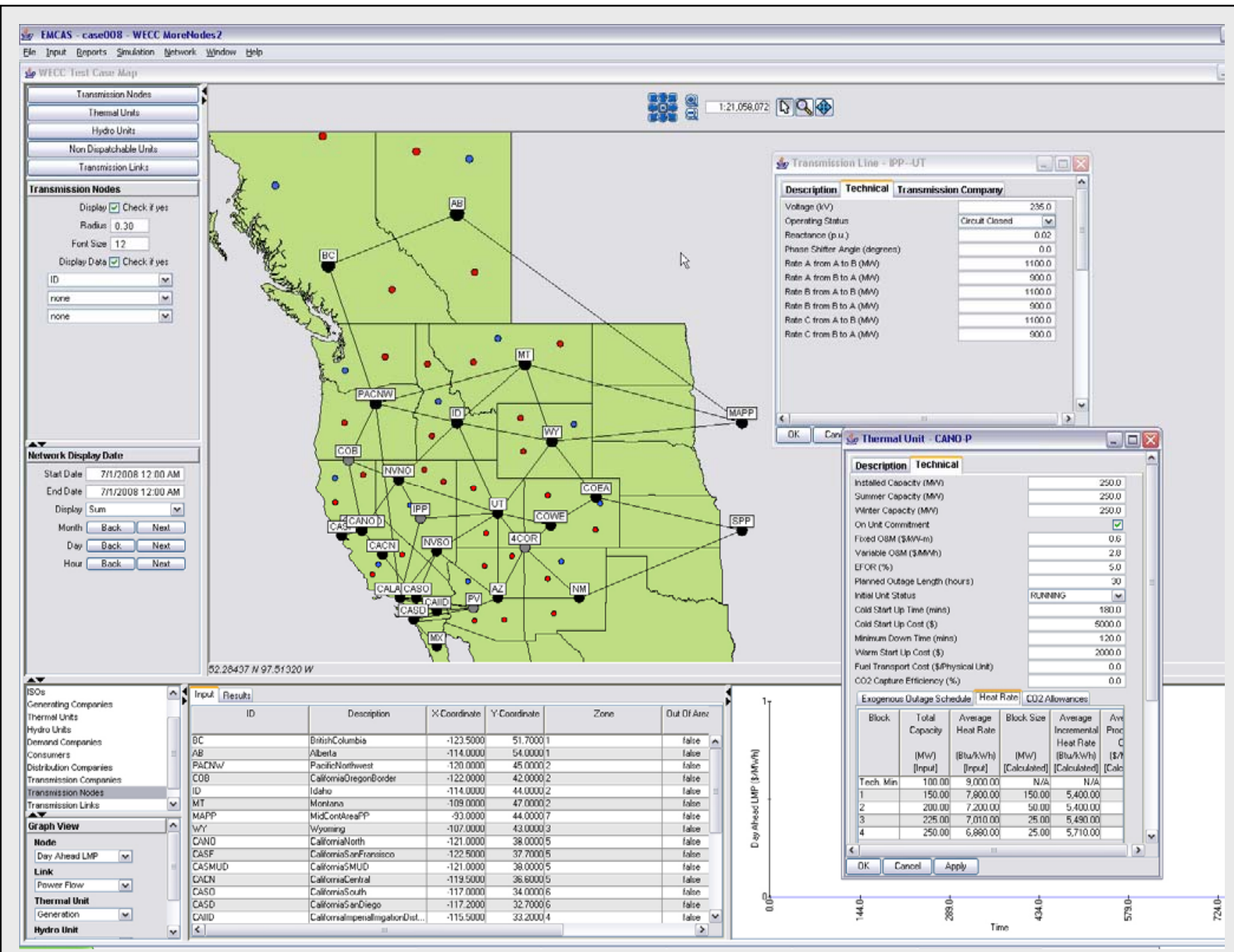

Figure 16 EMCAS Grid Configuration for the WECC

With this aggregate 28-zone (and 52-link) configuration, various potential water shortage situations could be examined in future project extensions. The analysis could indicate potential congestion issues under average and dry situations and quantify the additional strain on the thermal system under dry conditions, estimate the additional water consumption for thermal power generation, and identify potential "critical zones" where water availability may limit thermal generation.

Other team members conducted a detailed bus-level analysis, but with the focus on a few hours per year. Future EMCAS simulations will model 8,760 chronological hours under various water inflow scenarios.

\subsection{Water Withdrawals and Consumption}

Water is used for cooling (once-through, wet, dry, or hybrid) and for pollution controls, such as scrubbers, that remove sulfur from the flue gas. Water usage is expressed in terms of water withdrawals and water consumption. Water withdrawal is the amount of water withdrawn from the water source. 
Water consumed by thermal power plants is the amount of water used in the process and not returned to the environment. To the extent possible, data on water usage (both withdrawal and consumption) for this study were obtained from EIA-767. This form has data on the cooling system type (once-through, recirculating with a cooling tower, recirculating with cooling pond, and other), data on the quantity of water withdrawn and consumed by the cooling system, and the water source.

However, data were not always specified in the form for either cooling system type or quantities of water used. For generating units where the cooling system was specified but water use quantities were not specified, water use was obtained from NETL (2006a, b) reports estimating freshwater use by thermal electric power plants. For generating units where data were not given and it was known that cooling water was required (such as a natural gas-fired steam turbine), an assumption was made about the cooling system and/or its water use. If the generating unit obtained water from a freshwater source, the cooling system was assumed to be a recirculating type. Generating units using non-freshwater sources, such as seawater or sewage effluent, were assigned zero freshwater use. 
This page intentionally blank 


\section{BASELINE RESULTS - ENERGY}

\subsection{WECC Load Forecast}

Argonne projects electricity demand in the WECC-US region to grow from 695 terawatthours (TWh) in 2005 to 1,011 TWh in 2025, with a corresponding growth in peak load from 135 to 195 gigawatts (GW) over the same time period. This growth in load, in combination with projected retirements of existing units and the need to maintain a $15 \%$ reserve margin, leads to the need to bring on new capacity on the order of 78 GW by 2025. Figure 17 shows the capacityload balance for the WECC system, illustrating the development of existing and new generating capacity versus peak load until 2025.

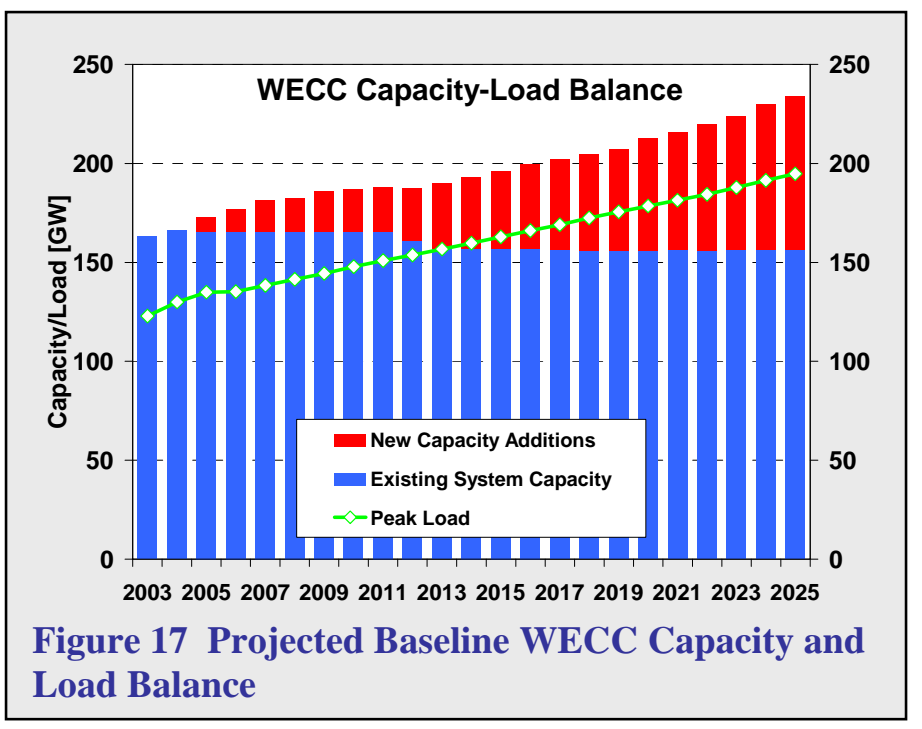

\subsection{WECC Capacity and Generation Projections}

Figure 18 illustrates the development of generating capacity and electricity generation by technology type. Total installed capacity grows from $173 \mathrm{GW}$ in 2005 to $233 \mathrm{GW}$ in 2025. Other fossil steam drops from 20 to $11 \mathrm{GW}$, while capacities of coal and renewables increase from 32 to $73 \mathrm{GW}$ and 58 to $71 \mathrm{GW}$, respectively. Total generation increases from 695 TWh in 2005 to 1,011 TWh in 2025 with coal accounting for $51 \%$ ( $510 \mathrm{TWh}$ ) of total generation by 2025. Natural gas generation drops from 193 to 142 TWh while renewables increase from 199 to 260 TWh over the same period.

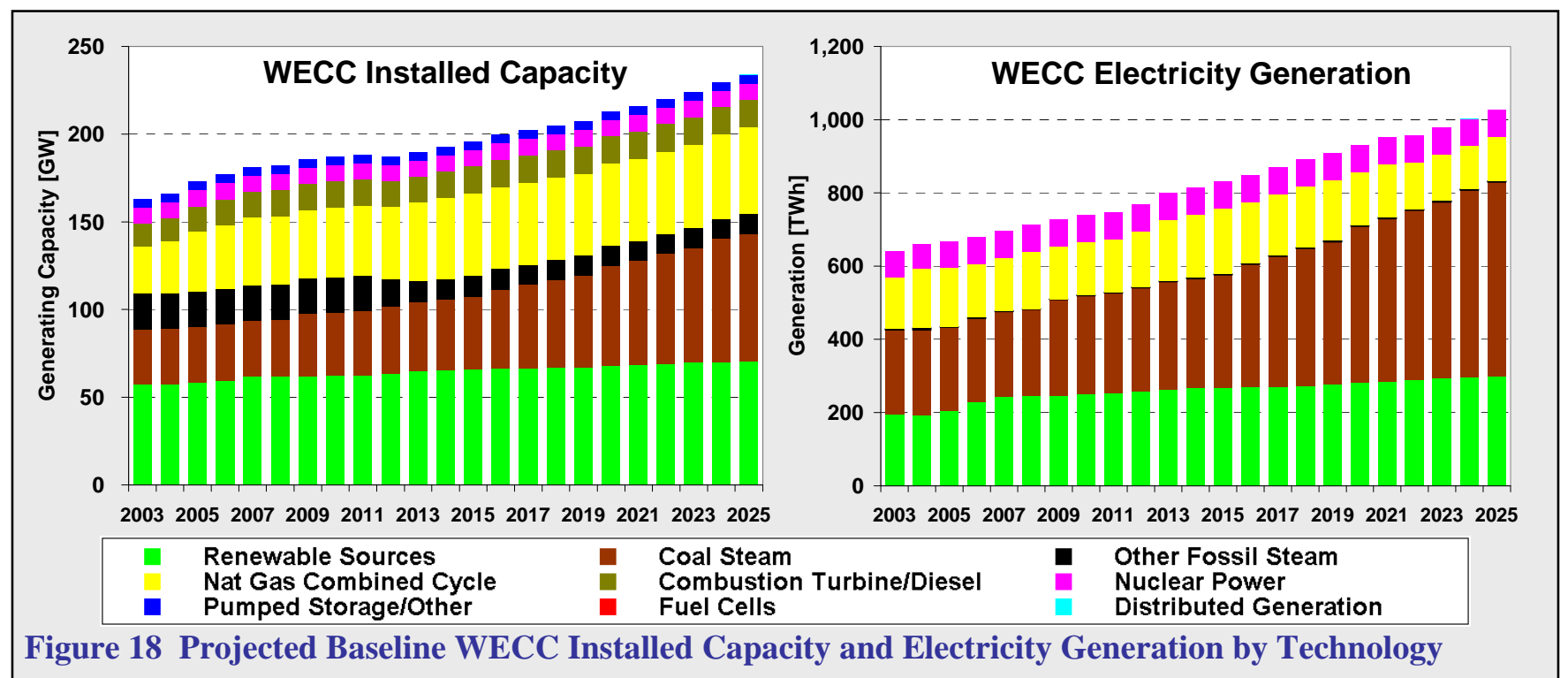


Figure 19 shows the technology mix of the new capacity additions. By 2025, a total of $78 \mathrm{GW}$ of new capacity is projected to come on-line. Coal takes the largest share, with $41 \mathrm{GW}$ (53\% of total additions) followed by $20 \mathrm{GW}$ of gas-fired combined cycles (26\%) and $13 \mathrm{GW}$ of renewables (17\%).

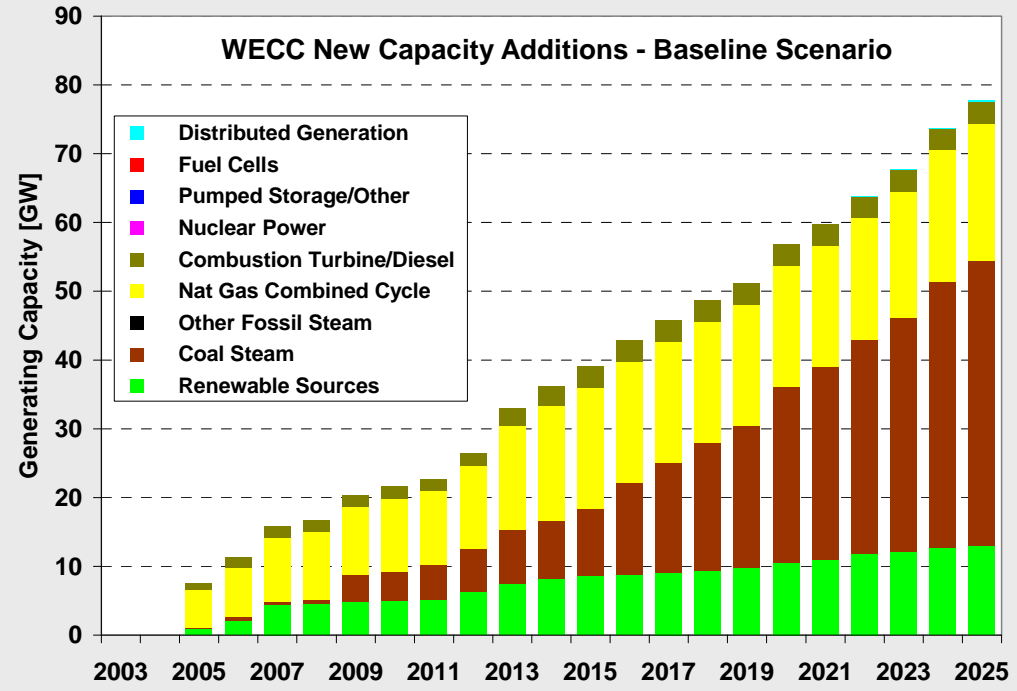

Figure 19 Projected Baseline WECC New Capacity Additions by Technology

Figure 20 provides a breakdown of renewable capacity and renewable generation for the WECC system until 2025. Conventional hydro capacity essentially stays flat at around 50 to $52 \mathrm{GW}$, while geothermal and wind increase from 2.2 to $6.5 \mathrm{GW}$ and 4.4 to $9.5 \mathrm{GW}$, respectively. Most of the renewable capacity additions come from wind (5.1 GW), geothermal $(4.3 \mathrm{GW})$, and hydro $(1.7 \mathrm{GW})$, with the remaining balance coming from smaller amounts of solar thermal and solar photovoltaic, municipal solid waste, and wood/biomass.

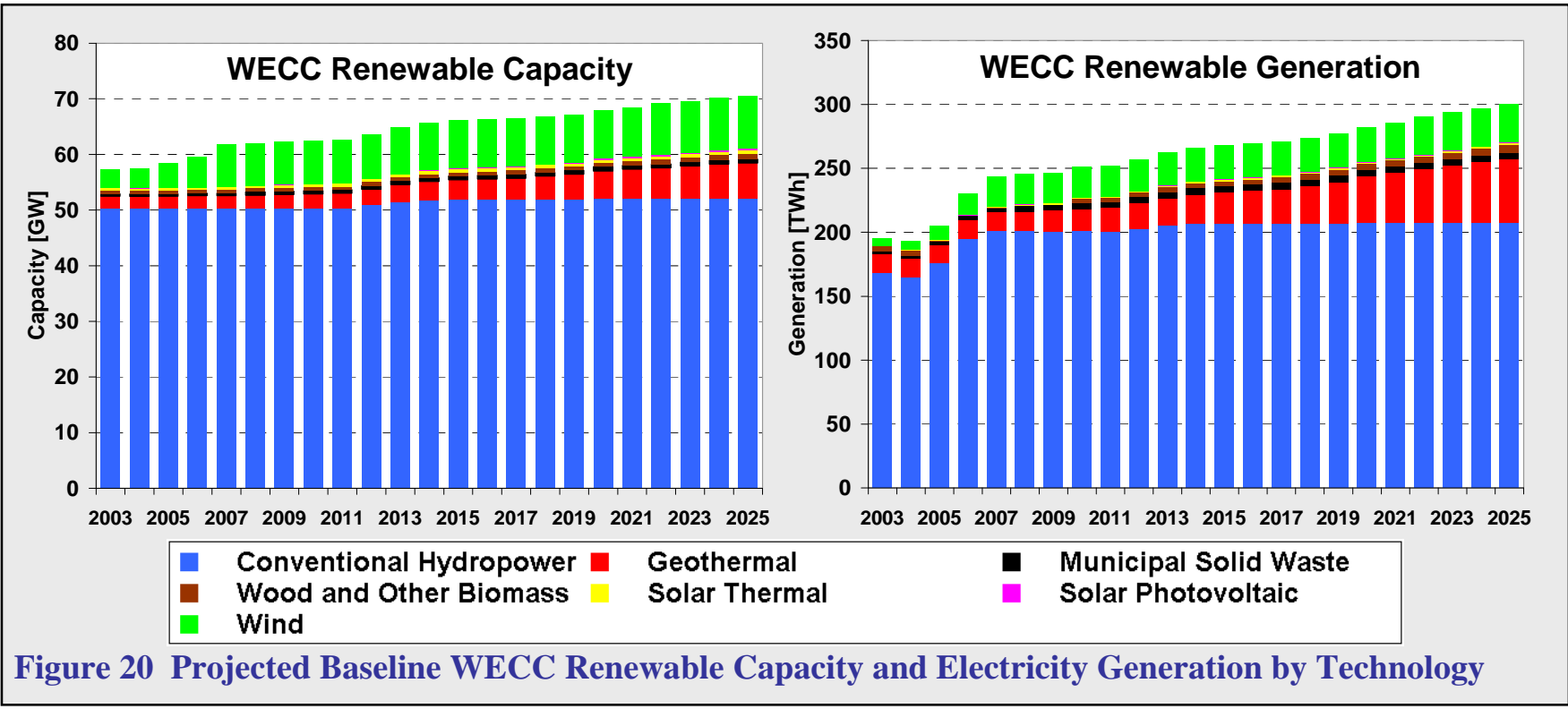




\subsection{WECC Regional Results}

The following graphs show similar results, but with a regional breakdown into three main WECC regions, including the NWPP, RMPA/AZ, and California. Figure 21 shows the load and capacity balance for the three regions. Figure 22 presents the capacity projections, while Figure 23 shows the power generation by technology. Figure 24 displays the new capacity additions. Figures 25 and 26 present additional details on the projected renewable capacities and generation levels.

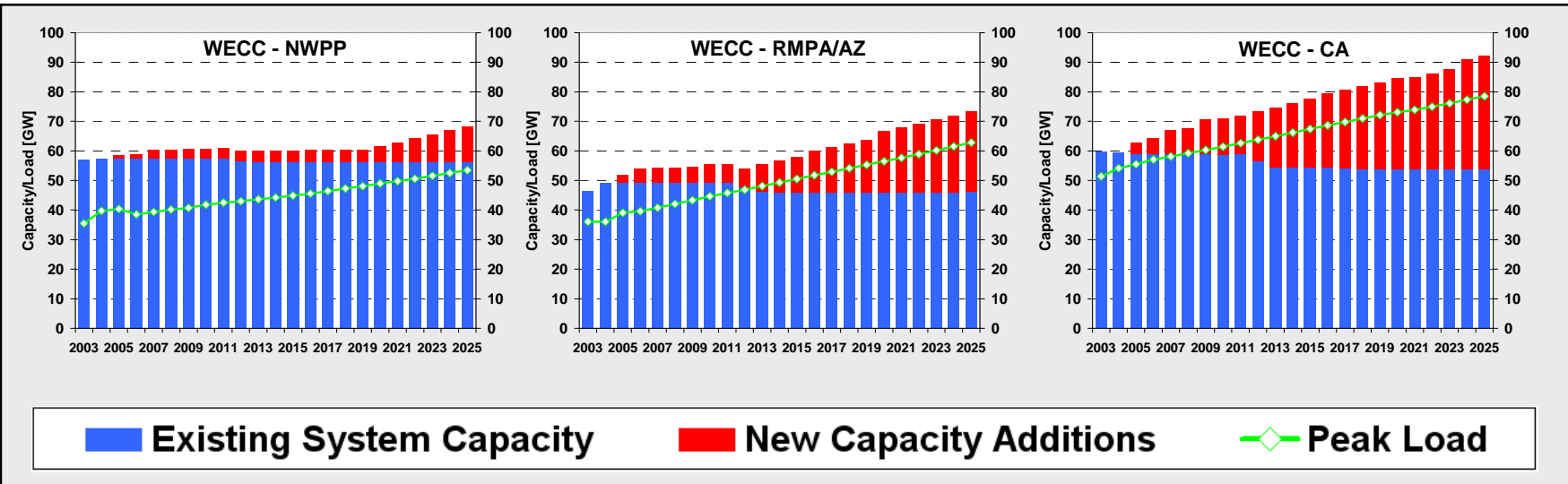

Figure 21 Projected Baseline Capacity and Load Balance by Main WECC Region

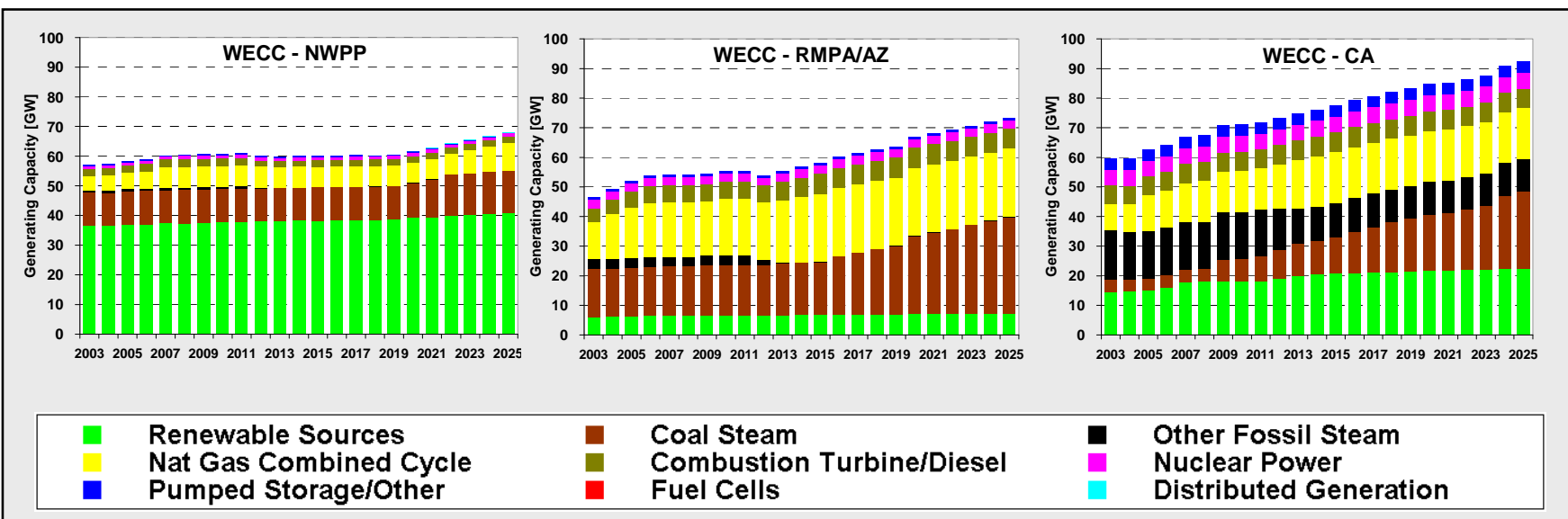

Figure 22 Projected Baseline Generating Capacity by Technology and Main WECC Region 


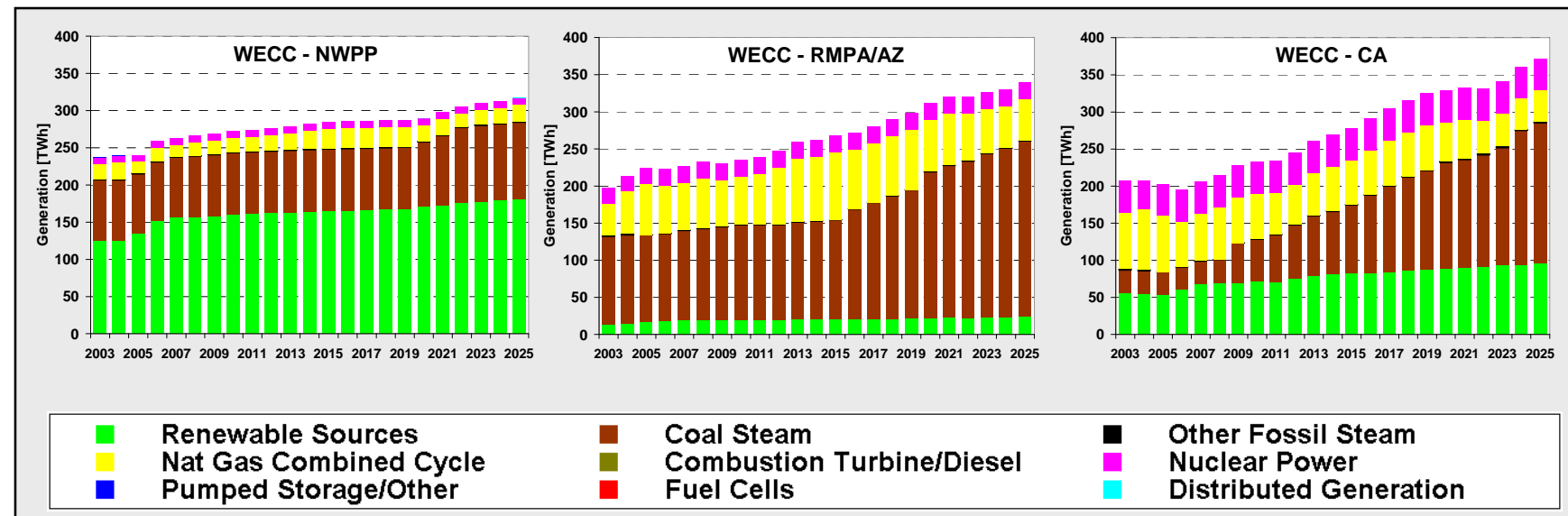

Figure 23 Projected Baseline Electricity Generation by Technology and Main WECC Region
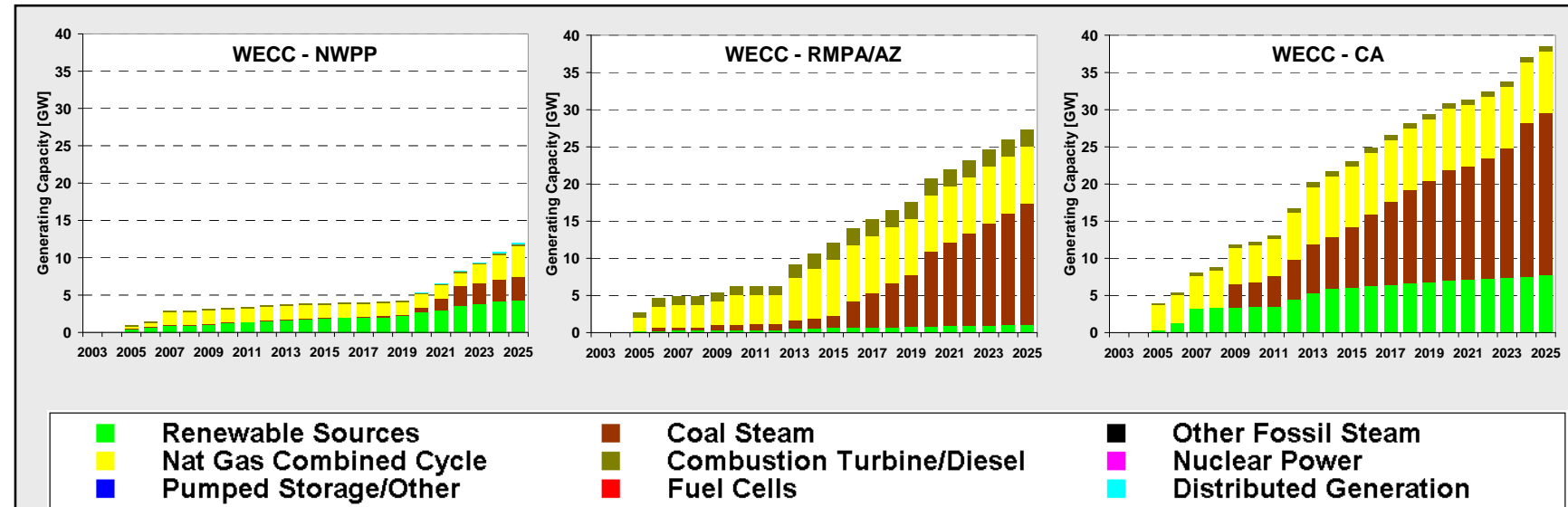

Other Fossil Steam
Nuclear Power
Distributed Generation

Figure 24 Projected Baseline New Capacity Additions by Technology and Main WECC Region
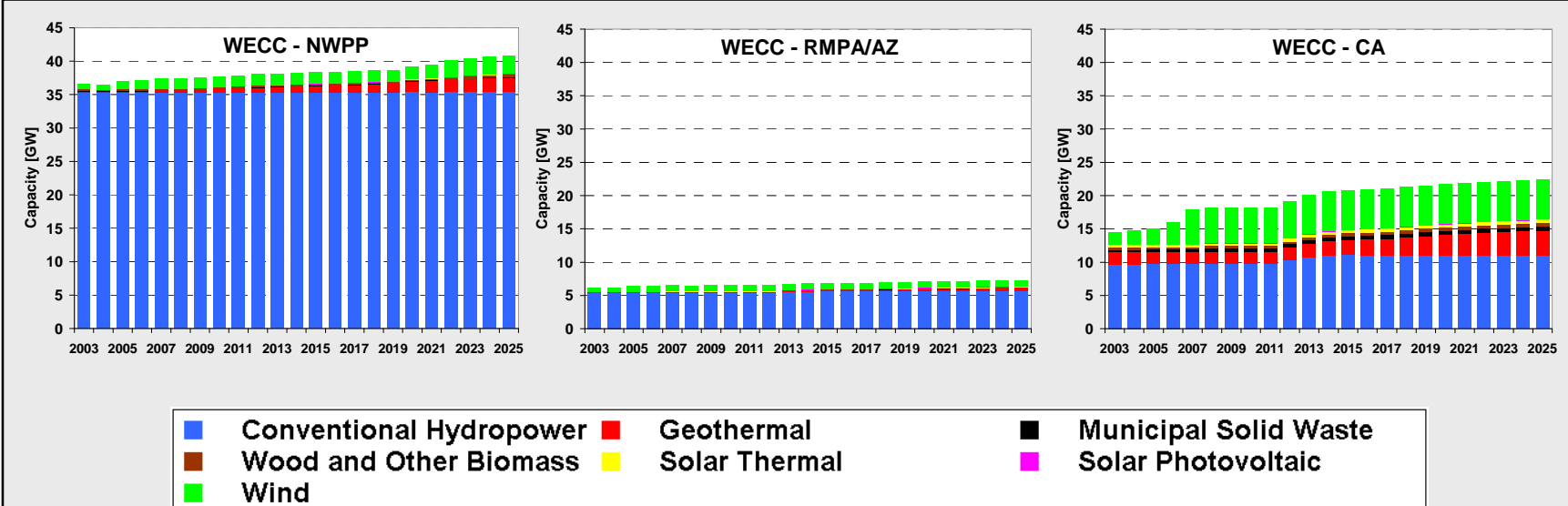

Geothermal

Solar Thermal

Municipal Solid Waste

Solar Photovoltaic

Figure 25 Projected Baseline Renewable Capacity by Technology and Main WECC Region 


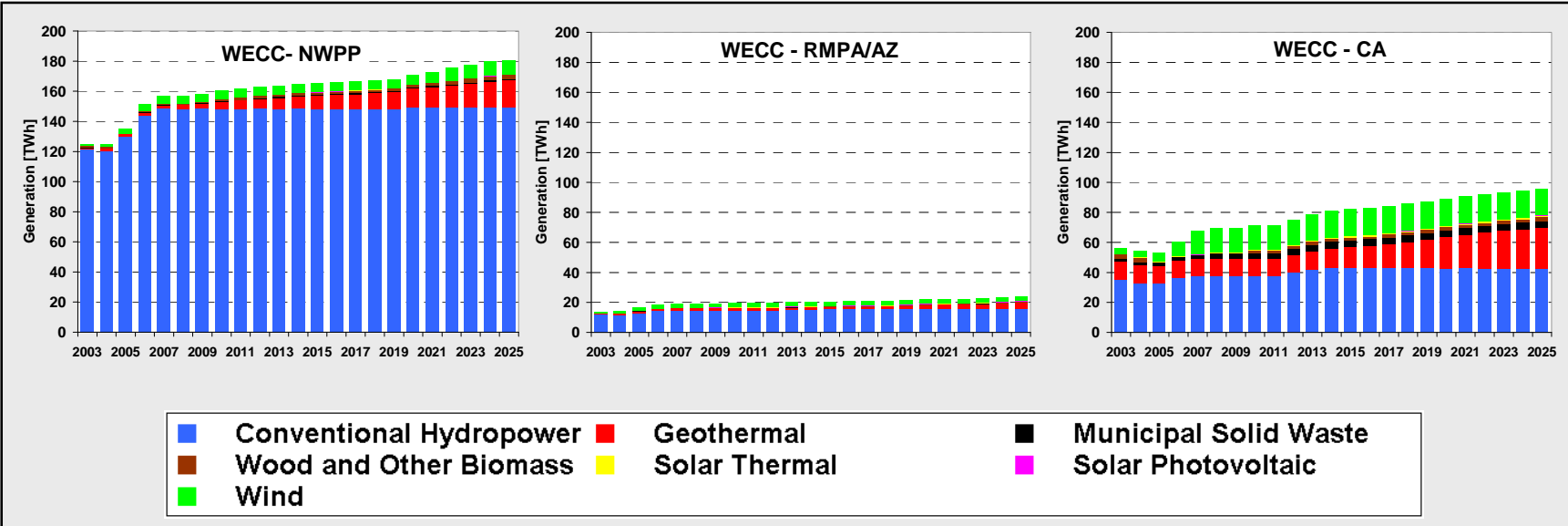

Figure 26 Projected Baseline Renewable Electricity Generation by Technology and Main WECC Region 
This page intentionally blank 


\section{BASELINE RESULTS - WATER AND OTHERS}

In 2005, water withdrawals for thermal power generation in WECC-US are estimated at 698 billion gallons per year (BGY) or 1.9 billion gallons per day. Water is withdrawn for cooling (once-through, wet, dry, or hybrid) and pollution controls, such as scrubbers, that remove sulfur from the flue gas.

Coal generation accounts for $72 \%$ of withdrawals, or about 501 BGY. The top four states are New Mexico with 248 BGY (36\%), Arizona with 126 BGY (18\%), California with 110 BGY (16\%), and Wyoming with 88 BGY (13\%). As shown in Figure 27, almost all of New Mexico's water withdrawals are for coal-fired power generation (241 BGY or $97 \%$ at its Four Corners station alone). Natural gas-fired power stations account for about $44 \%$ of water withdrawals in Arizona; the rest is used in coal-powered units. California's water withdrawals are mostly for its natural gas-fired power stations (98\%), while coal power stations account for all of Wyoming's withdrawals. Figure 27 also shows the water withdrawal per megawatthour (MWh) of power generation (withdrawal intensity) in each state. For the entire WECC region, the 2005 withdrawal intensity is 1,006 gal/MWh. Yet the states show substantial variations, ranging from $75 \mathrm{gal} / \mathrm{MWh}$ in Idaho (high proportion of hydro) to about 7,970 gal/MWh in New Mexico.

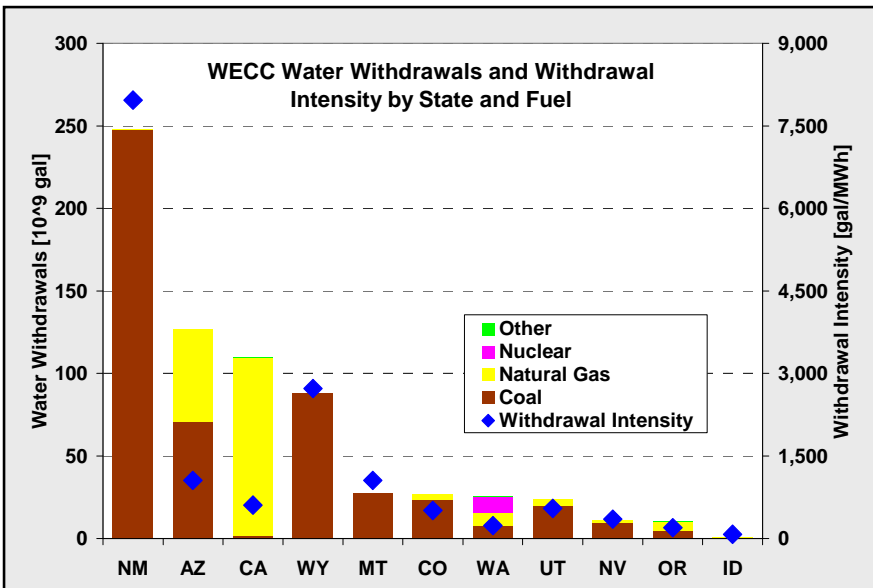

Figure 272005 Water Withdrawals by State and Primary Fuel

It is important to recognize that most of the water withdrawn for cooling is not consumed but is returned to the original source of water, such as lakes and rivers, however, at an elevated temperature level (approximately $20^{\circ} \mathrm{F}$ above the source ambient temperature). For all of the WECC, actual water consumption due to evaporation in cooling processes and use in pollution controls totals about 223 BGY or about 32\% of total withdrawals. Figure 28 shows water consumption by state and primary fuel; Figure 29 presents a state-by-state comparison of withdrawals and consumption. A number of observations can be made from these two figures. First, the state-by-state consumption pattern looks noticeably different. Second, the variation in consumption intensity across states is much less pronounced, with a range from 72 to 626 gal/MWh. Third, in Arizona, California, New Mexico, Montana, and Wyoming, actual water consumption is only a smaller fraction of the total withdrawals (26\%-59\%), while in Colorado, Idaho, Nevada, Oregon, and Utah, $90 \%$ or more of

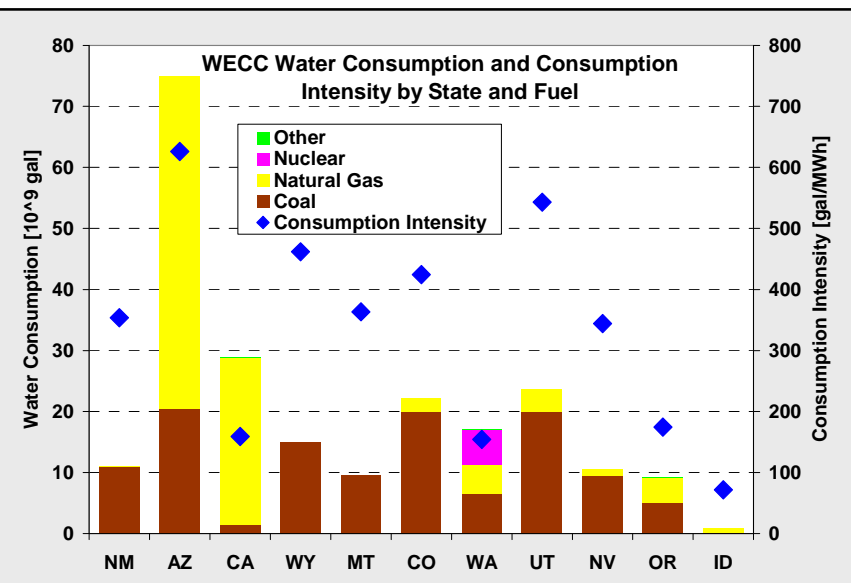

Figure 28 Water Consumption by State and Primary Fuel 
the water withdrawn is consumed. The observed variations and differences in water withdrawal, consumption, and intensity are due to the interplay of the type of cooling system (once-through vs. recirculating) and how much electricity the units generate (that is, their size and capacity factor). Figure 30 shows the state-by-state electricity generation by fuel type for 2005. Figure 31 presents the makeup of freshwater cooling systems by state.

New Mexico’s very high water withdrawals (see Figure 27) and the large difference between withdrawals and consumption (see Figure 29) are related to the Four Corners station, which

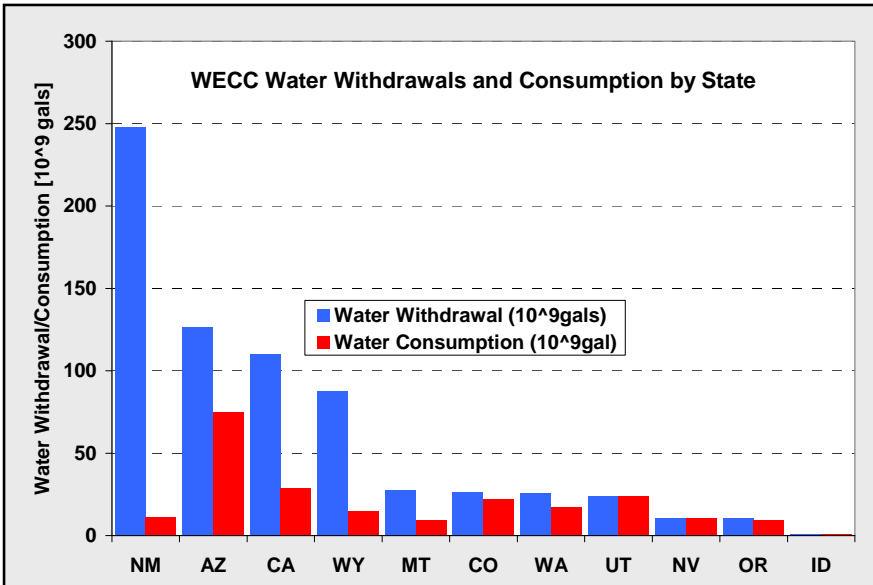

Figure 292005 Water Withdrawals and Consumption by State

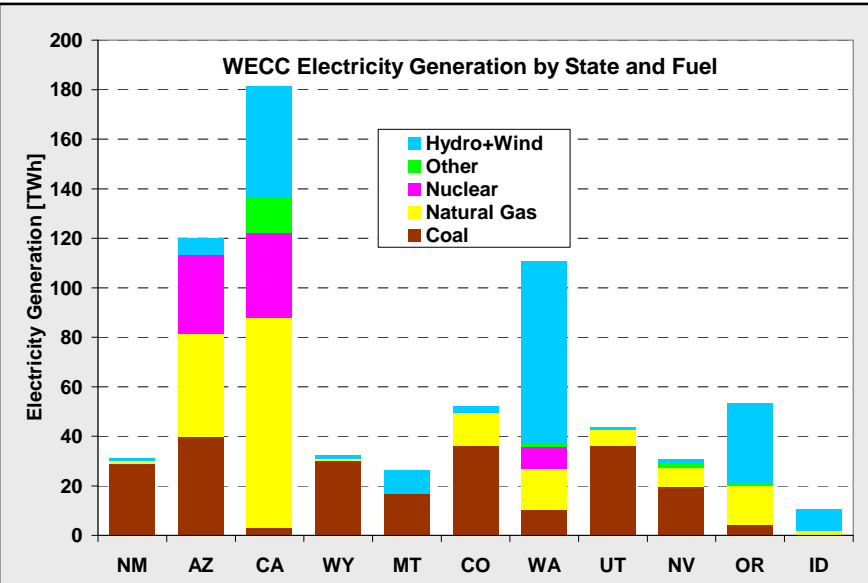

Figure 302005 Electricity Generation by State and Primary Fuel recirculating systems.” Other plants in New Mexico use recirculated cooling. This assumption explains the very high water withdrawal and withdrawal intensity for New Mexico, particularly compared to Arizona, Colorado, Nevada, Utah, and Wyoming, all of which have similar levels of coal power generation (see Figure 30).

The higher withdrawal intensities and the differences between withdrawals and consumption seen for Montana and Wyoming in Figures 27 and 29 are largely because of numerous coal units that use oncethough cooling, which has substantially higher withdrawal requirements (but low consumption) as opposed to recirculated cooling. In Montana, the key contributor is the Corette station with a oncethrough cooling system. Corette accounts for 7\% (158 MW) of the 2,359 MWs of Montana plants that use water, and it is base loaded. Other plants in Montana use recirculated cooling. In Wyoming, the largest water user is the once-through cooling system of the three Dave Johnston units; this plant accounts for $10 \%$ (432 MW) of the 4,157 MW of Wyoming plants that use water. It is also base loaded. 
Comparing Nevada with Montana and Wyoming, shows that despite very similar coal generation levels, Nevada has a much lower withdrawal intensity. The reason is that almost all coal units in Nevada use recirculated cooling. Only one coal plant in Nevada uses a cooling pond with data coming from EIA-767. The two units at the Fort Churchill plant comprise $226 \mathrm{MW}$ (or only 3.7\%) of the 6,043 MW of plants that use water in Nevada. Furthermore, in 2005, the Churchill units each had a capacity factor of as low as $0.3 \%$. Again, the discrepancies in water intensity between these states appear to be a function of the type of cooling system (once-through or pond vs. recirculated) and also how much the high-water-

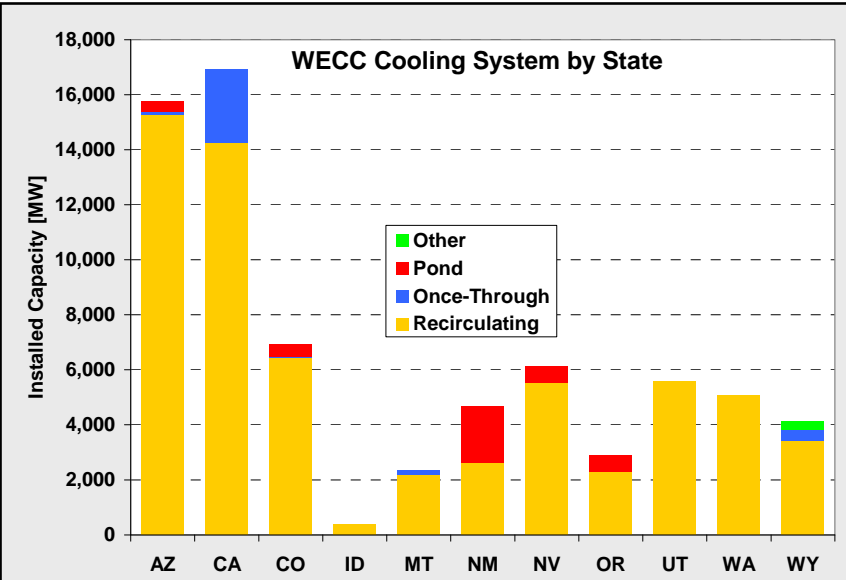

Figure 312005 Cooling Technology by State and Primary Fuel use plants operated in 2005.

For the State of Washington, only freshwater withdrawals and consumption were observed for nuclear power generation. The Columbia Generating Station uses recirculated cooling with water from the Columbia River. On the other hand, the three nuclear power plants at Palo Verde, Arizona, have oncethrough cooling. However, Palo Verde is the only nuclear station that uses treated sewage effluent as a source of cooling water. The effluent water comes from the City of Phoenix and is treated in an 80-acre reservoir for use in the plant's cooling towers. Therefore, freshwater withdrawal and consumption are zero. California's nuclear power stations (two units at San Onofre and two units at Diablo Canyon) are located on the coast and use seawater for cooling, so their freshwater use is also zero.

In general, water consumption in some states is close to withdrawals; in other states, consumption is noticeably below withdrawals. In Colorado, Idaho, Nevada, Oregon, and Utah, consumption is closer to withdrawal (a ratio of consumption to withdrawal of about 0.9) because most generating units have recirculating cooling. In Colorado, only a 39-MW unit uses once-through cooling, and it had a capacity factor of $0.3 \%$ in 2005 . Idaho, Nevada, Oregon, and Utah have no units that use once-through cooling. The states where the consumption-to-withdrawal ratio is 0.3 to 0.6 have somewhat more once-through or pond cooling, but, more important, these plants appear to be operated at higher capacity factors. In the EIA-767 dataset, however, in some instances, withdrawal and consumption were identical, which could imply that discrepancies may in part be due to a reporting issue.

In conclusion, large differences between states in ratios of water consumption to water withdrawal and water intensity values can be caused by the interplay of several factors. First is the installed capacity of plants that use a specific type of cooling system as a percent of total installed capacity (see Figure 31). For example, once-through cooling systems withdraw much more water than they consume, while recirculating cooling systems withdraw much less water. Water consumption in recirculating cooling systems, however, can amount to about $85 \%$ of water withdrawal. Second is the amount of electricity that plants with various cooling system types generate. States with plants with large water withdrawal rates (gal/MWh) may have a low water withdrawal intensity if they have a low capacity factor because they seldom operate. 
Figures 32 and 33 present the 2005 water withdrawals and water consumption by county. The maps clearly show the geographical differences in water withdrawals and consumption.

For future projections, Argonne team members assumed that new capacity additions are more waterefficient than existing capacity. The following technology assumptions were made for new capacity, and water withdrawal and consumption factors were taken from NETL (2006a, b).

- New steam coal capacity: Supercritical, recirculating cooling, dry flue gas desulfurization, freshwater withdrawal rate of 648 gal/MWh, and consumption rate of 496 gal/MWh; and

- New natural gas combined-cycle capacity: Recirculating cooling, freshwater withdrawal rate of $150 \mathrm{gal} / \mathrm{MWh}$ and consumption rate of $130 \mathrm{gal} / \mathrm{MWh}$.

Projections of water withdrawals and water consumption under the baseline scenario are given in Figures 34 and 35. On the basis of projected retirements and new capacity additions presented in Section 4 as well as the technology assumptions above, the baseline annual water withdrawals are projected to decline from 698 to 598 BGY in 2009 and then steadily increase to 677 BGY in 2025, which is slightly below the 2005 value. The initial drop from 2005 to 2006 is driven by historic and projected hydro power generation. In 2005, WECC had very low hydro generation because of a persistent drought in the Southwest. For forecasting purposes, Argonne assumed average hydro availability in future years under baseline conditions. The sensitivity of the projection results and vulnerability of the system to continuing drought conditions will be investigated in more detail in future analyses.

Given that new capacity additions have lower marginal water withdrawal rates than the current capacity, the average regional withdrawal intensity progressively declines by 33\% - from 1,004 gal/MWh in 2005 to $669 \mathrm{gal} / \mathrm{MWh}$ by 2025.

Water consumption is projected to first decline somewhat and then increase by about $29 \%$ from 223 BGY to around 287 BGY over the analysis period. The average regional water consumption intensity is forecast to decline from $321 \mathrm{gal} / \mathrm{MWh}$ in 2005 to $284 \mathrm{gal} / \mathrm{MWh}$ in 2025. This represents a drop of $12 \%$ as compared to a $33 \%$ drop in withdrawal intensity. The impact on the consumption intensity is smaller because the marginal consumption rate for new coal units (496 gal/MWh) is above the average regional 2005 rate (321 gal/MWh). While gas and renewable capacity additions lead to a reduction in the average consumption intensity, the coal capacity additions have the opposite effect. The net result is a reduced overall impact on the consumption intensity.

Finally, Figures 36 and 37 show the current and projected regional $\mathrm{CO}_{2}$ emissions under the baseline scenario. Arizona, Colorado, California, and Utah are the top four $\mathrm{CO}_{2}$ emitters in 2005. Arizona is the largest source of power sector $\mathrm{CO}_{2}$ emissions, with 64 million tons (18\% of total WECC emissions in 2005). Emissions are expected to increase by 65\% from 346 to 571 million tons over the projection period. The $\mathrm{CO}_{2}$ intensity slightly increases by $13 \%$, from 0.50 to 0.56 tons/MWh. 


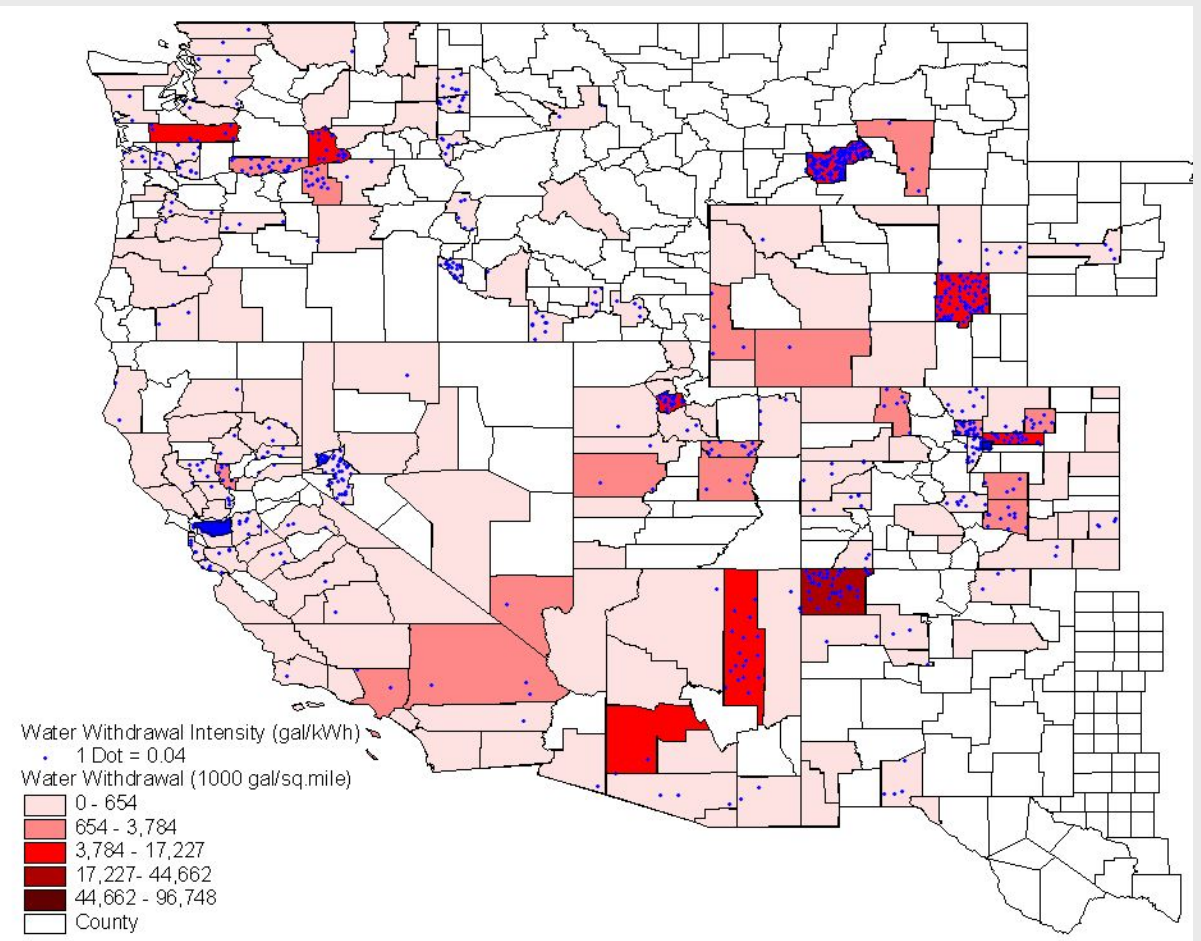

Figure 322005 Water Withdrawals for Thermal Power Generation by County

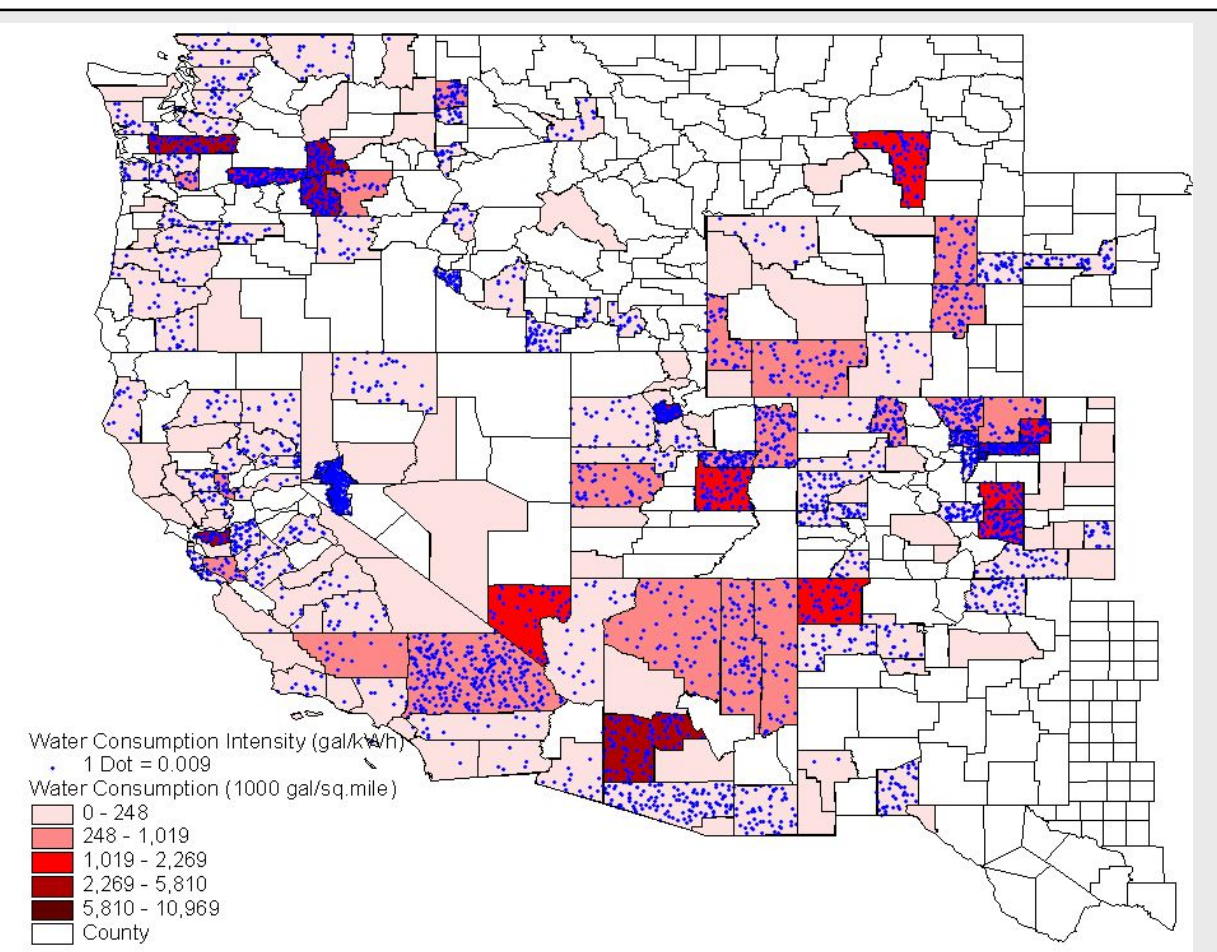

Figure 332005 Water Consumption for Thermal Power Generation by County 


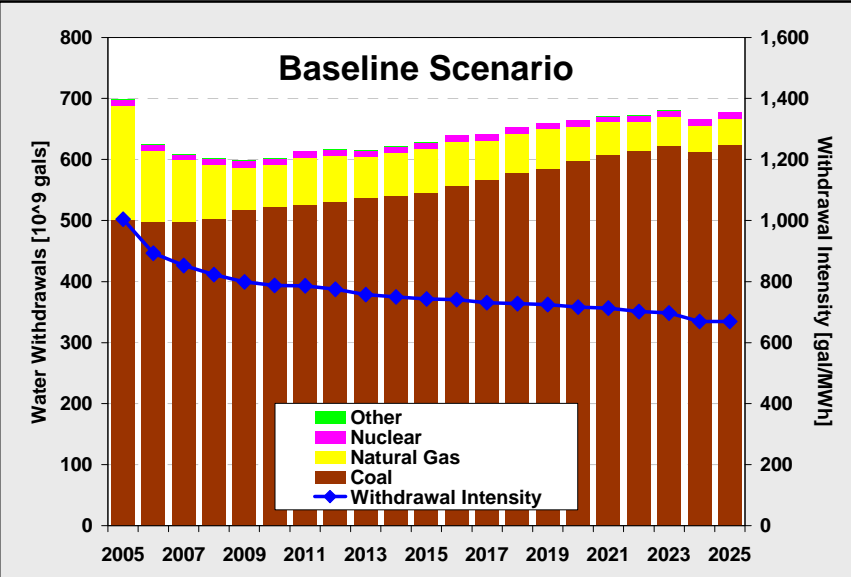

Figure 34 Projected Baseline Water Withdrawals by Primary Fuel

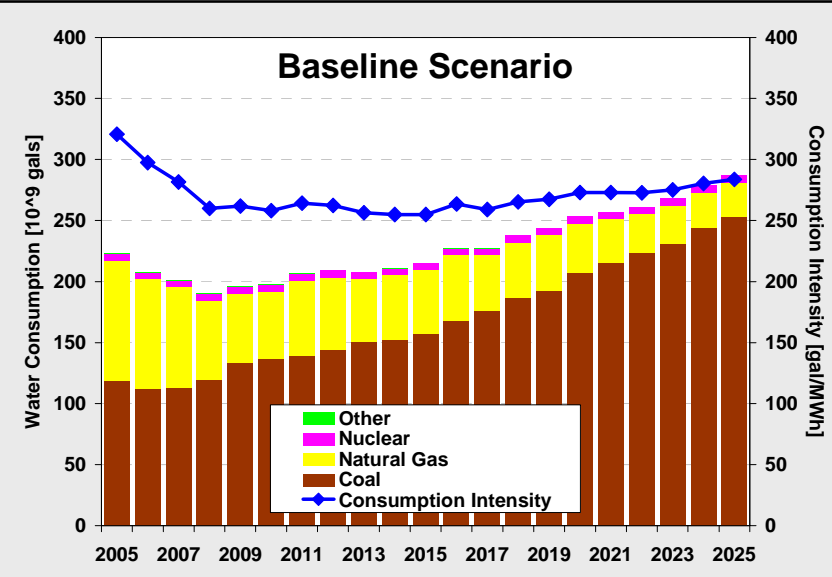

Figure 35 Projected Baseline Water Consumption by Primary Fuel

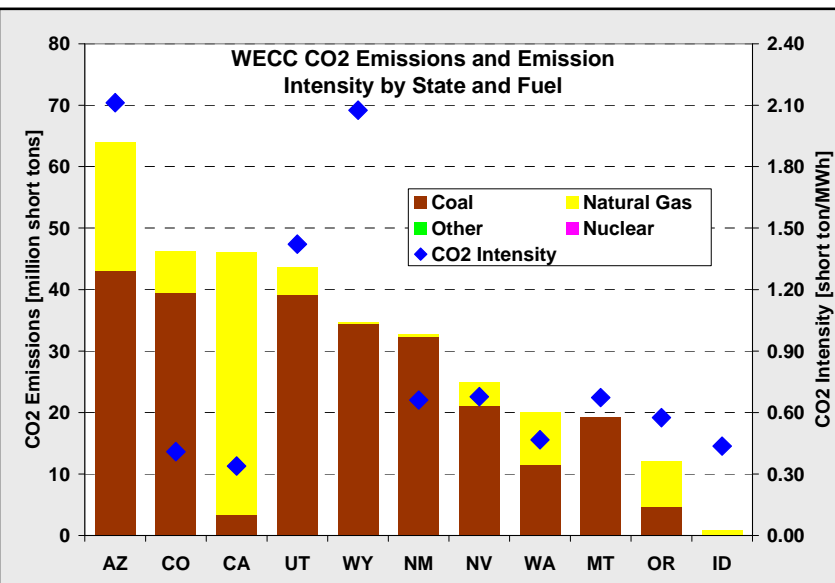

Figure 362005 Power Sector $\mathrm{CO}_{2}$ Emissions by State and Primary Fuel

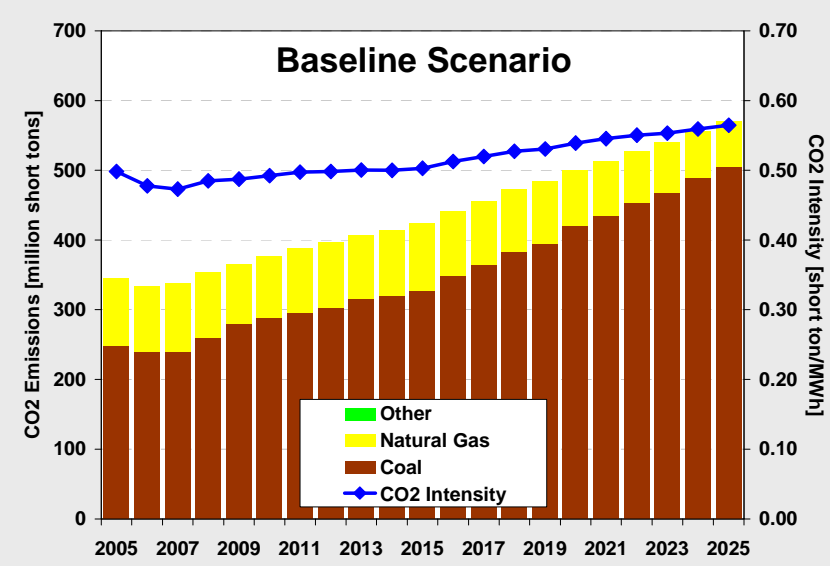

Figure 37 Projected Baseline Power Sector $\mathrm{CO}_{2}$ Emissions by Primary Fuel 


\section{ALTERNATIVE SCENARIO RESULTS - WATER AND OTHERS}

This section presents results of two alternative scenarios that examine the impact on projected WECC water withdrawal and consumption levels and on $\mathrm{CO}_{2}$ emissions. The current preliminary set of scenarios looks at alternative power generation technologies. Future work will focus on additional options and scenarios, including the impact of demand-side management programs on future power sector water withdrawals and consumption, the effects of different cooling and pollution control technologies, as well as grid constraints and grid expansion options. In developing the two scenarios, several key assumptions were made; these are discussed in Sections 6.1 and 6.2. Section 6.3 summarizes both scenarios.

\subsection{Renewables Scenario}

- An aggressive renewables program is assumed to be implemented that goes beyond levels discussed in current renewable portfolio standards; that is, Argonne assumes that under this scenario, 25\% of the demand would be supplied by renewable resources (excluding conventional hydropower) by 2025. The increase in renewable generation was assumed to be achieved mainly by additional wind farm capacity, while the capacity additions of other renewable sources (e.g., geothermal, municipal solid waste, biomass, and solar) remained the same as in the baseline analysis.

- Under this scenario, $65.4 \mathrm{GW}$ of new renewable capacity is added to the system, 89\% or $58.4 \mathrm{GW}$ of which is wind power. This compares to $13.2 \mathrm{GW}$ of renewable additions (6.2 GW of wind) under the baseline scenario. Renewable additions represent $52 \%$ of all new capacity installations by 2025, amounting to $124.6 \mathrm{GW}$ or $44 \%$ of total installed capacity in the WECC region $(280.7 \mathrm{GW})$. In comparison, the total capacity of the WECC system in 2025 under the baseline scenario was $233.7 \mathrm{GW}$. Total renewable generation, including conventional hydro, is projected to grow to 465 TWh or $45 \%$ of total WECC generation by 2025, compared to 300 TWh, or 29\% under the baseline scenario.

\subsection{Nuclear Scenario}

- An aggressive nuclear program is assumed to be implemented under this scenario. Starting from 2017, which is considered the first year in which new nuclear power plants may come on-line, it is assumed that all new conventional capacity additions would consist of nuclear units only. The additions of renewable generating capacity under this scenario remain the same as in the baseline analysis. This resulted in the addition of $28.5 \mathrm{GW}$ of new nuclear capacity to the system by 2025. Zero freshwater withdrawal/consumption is assumed for nuclear; that is, the new nuclear plants use either dry cooling technologies or seawater as a cooling water source.

- Nuclear accounts for 38\% of all new capacity additions. By 2025, the nuclear capacity share grows to $16 \%$ from $5 \%$ in 2005. Nuclear power generation increases from 72.6 TWh to 299.9 TWh over the forecast period and provides $29 \%$ of total generation. Figure 38 shows the projected capacity additions under the baseline and alternative scenarios. 

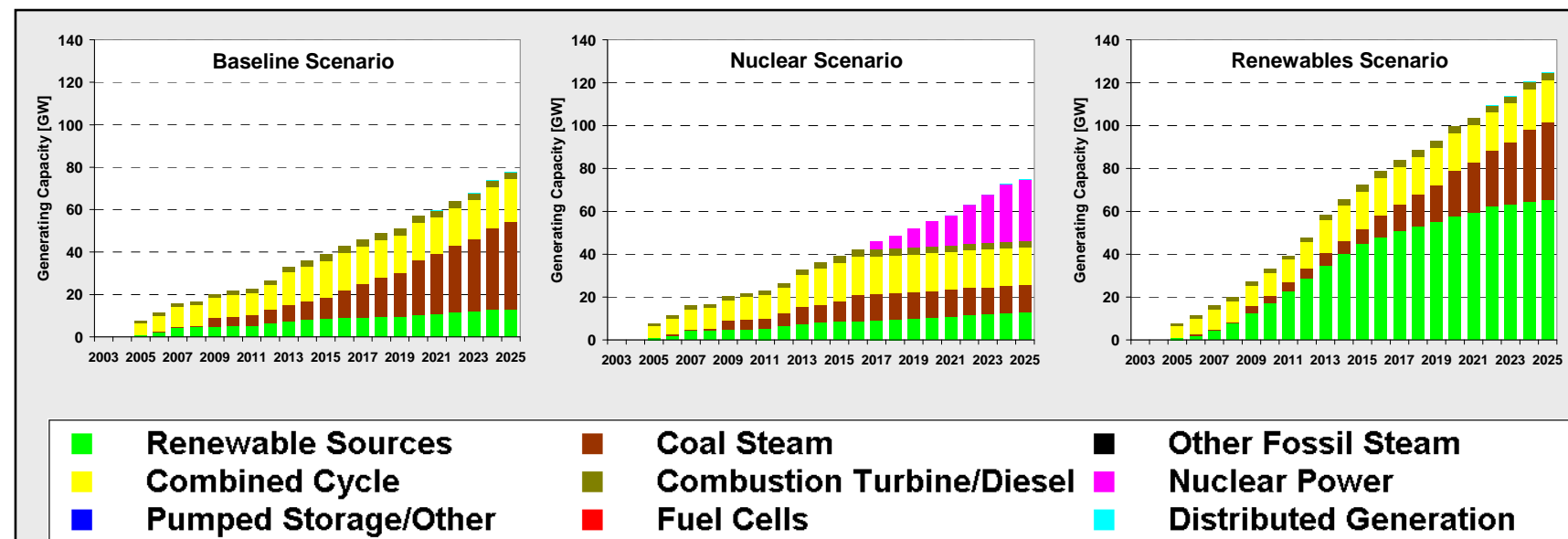
- Coal Steam
Combustion Turbine/Diesel
Fuel Cells

Other Fossil Steam

Nuclear Power

Distributed Generation

Figure 38 Projected New Capacity Additions by Scenario and Technology

\subsection{Discussion by Scenario}

Figure 39 shows the effect on projected water withdrawals and withdrawal intensities under the baseline and alternative scenarios. While under the baseline scenario, total withdrawals in 2025 are projected to be only slightly below 2005 levels, an expanded use of renewables or nuclear can reduce 2025 withdrawals by 23\%-25\% below 2005 levels to approximately 526 (nuclear) to 537 BGY (renewables). The withdrawal intensity falls to $507 \mathrm{gal} / \mathrm{MWh}$ (nuclear) and to $522 \mathrm{gal} / \mathrm{MWh}$ (renewables).

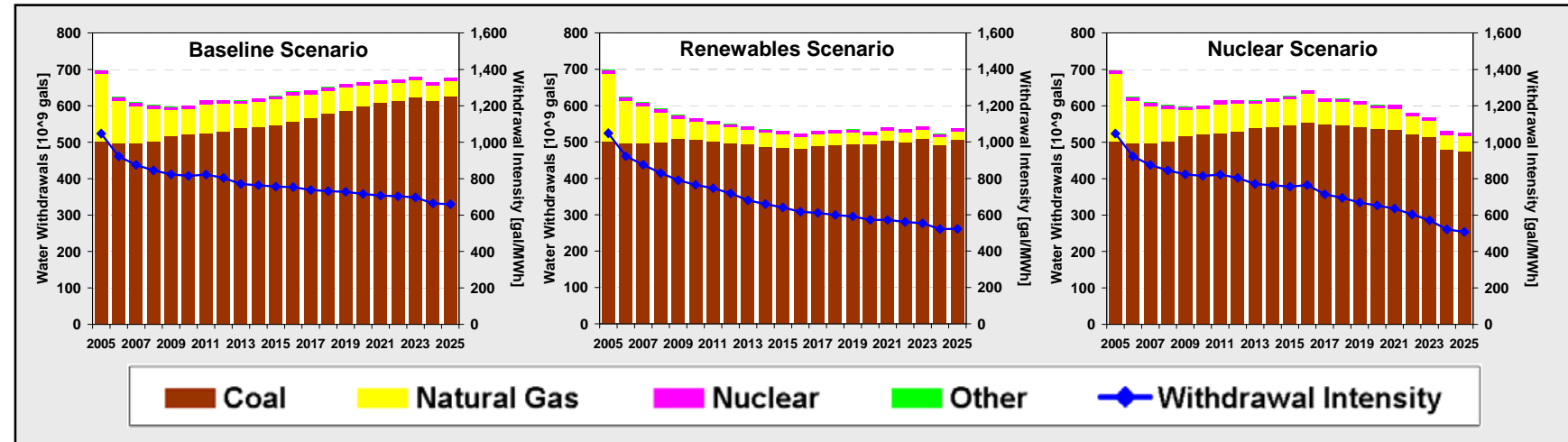

Figure 39 Projected Water Withdrawals and Withdrawal Intensity by Scenario

The impact on water consumption is even more pronounced (see Figure 40). Under the renewables scenario, 2025 consumption levels are 22\% below the baseline scenario, while under the nuclear scenario, the reduction is as high as $38 \%$. Water consumption in the baseline is projected to grow by $29 \%$ over the entire analysis period to about 287 BGY. With expanded renewables, consumption can be stabilized (245 BGY) and with nuclear even reduced by 20\% (178 BGY). While in the baseline scenario, consumption intensity drops by $12 \%$ (from 321 to 284 gal/MWh) by 2025, under the renewables scenario the decline is 35\% (218 gal/MWh), and in the nuclear scenario close to 50\% (172 gal/MWh). 


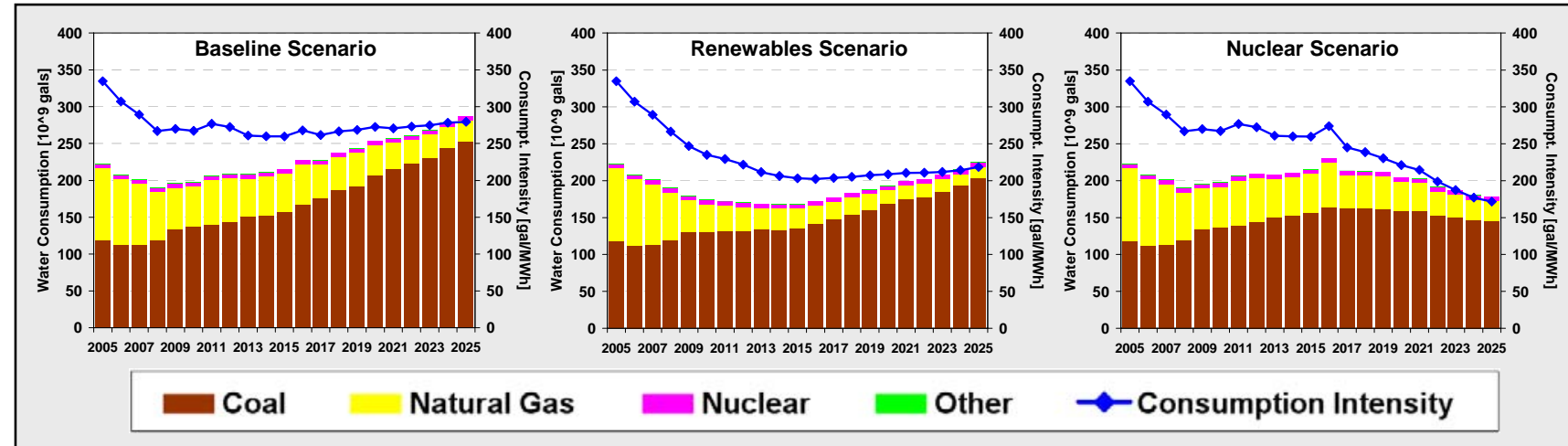

Figure 40 Projected Water Consumption and Consumption Intensity by Scenario

Figure 41 presents projected emissions of $\mathrm{CO}_{2}$ under all three scenarios. Emissions are forecast to grow by $65 \%$ from 346 to 571 million tons per year. This noticeable increase in absolute emissions translates into a $7 \%$ increase in $\mathrm{CO}_{2}$ intensity. Both alternative scenarios have a noticeable effect on projected emissions and emission intensity. Under the renewables scenario, emissions grow only by $29 \%$ to 445 million tons, while $\mathrm{CO}_{2}$ intensity drops by $17 \%$ to 0.43 tons/MWh. With expanded nuclear, $\mathrm{CO}_{2}$ emissions almost return to 2005 levels (369 million tons or $7 \%$ above 2005 levels), which is $35 \%$ below baseline 2025 levels. The $\mathrm{CO}_{2}$ intensity drops to 0.36 tons/MWh.

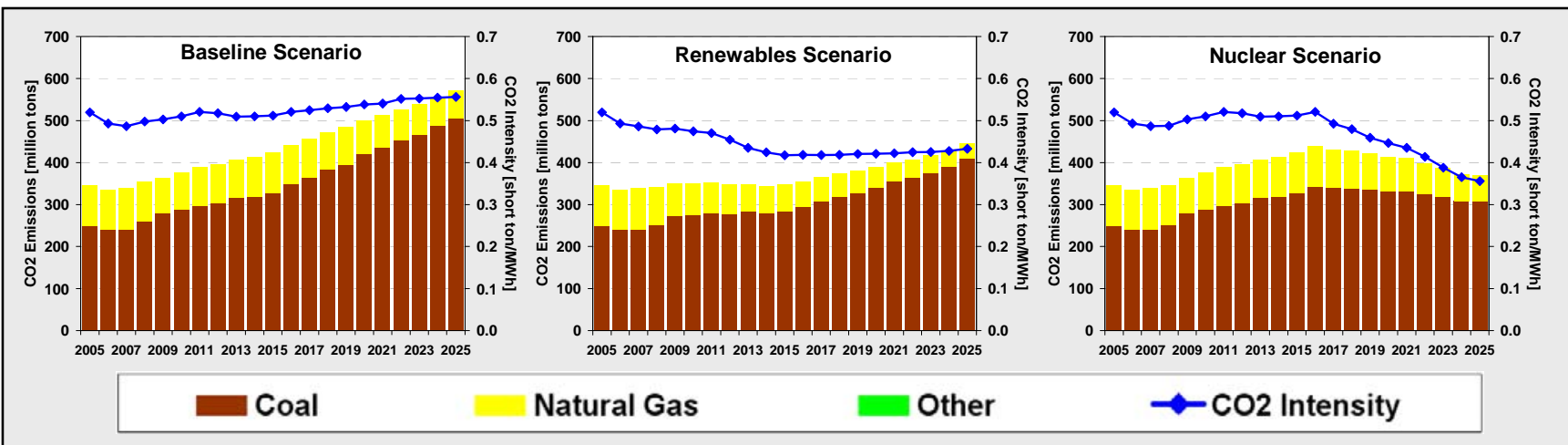

Figure 41 Projected $\mathrm{CO}_{2}$ Emissions and Emission Intensity by Scenario 
Figure 42 compares projected levels of water withdrawals, water consumption, and $\mathrm{CO}_{2}$ emissions across the three scenarios.

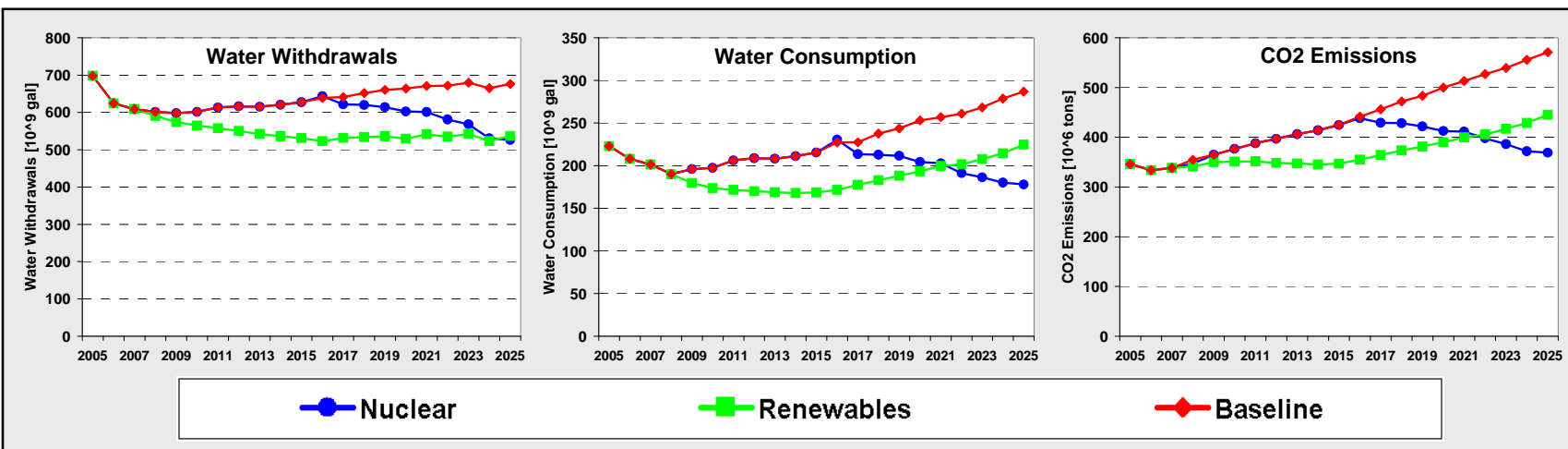

Figure 42 Projected Water Withdrawals, Water Consumption, and $\mathrm{CO}_{2}$ Emissions by Scenario 


\section{SUMMARY AND CONCLUSIONS}

Under baseline assumptions, water withdrawals are expected to initially decline and then slightly increase through 2025. Baseline water consumption is expected to significantly increase in the long term, but at a rate lower than load growth. Water intensity (both withdrawals and consumption) for power generation is expected to decrease over time, as new, more water-efficient technologies are brought on-line.

The aggressive pursuit of renewables and nuclear power could reduce water withdrawals and consumption significantly (close to $40 \%$ by 2025 as compared to the baseline). The impact is more pronounced under the nuclear scenario. In the renewables scenario (mostly wind), wind generation displaces both coal and natural gas-fired generation to moderately reduce water use. In the nuclear scenario, nuclear generation displaces base load coal generation, resulting in a delayed, but more rapid, reduction in water use.

Future work will focus on (1) evaluating additional technology and policy options, such as demand-side management and cooling technologies; (2) performing uncertainty analyses, particularly as they relate to hydro power variability; (3) assessing the impacts of grid constraints; and (4) estimating water consumption associated with fossil-fuel extraction, processing, and refining. 
This page intentionally blank 


\section{BIBLIOGRAPHY}

EIA (Energy Information Administration), 2006a, Annual Energy Outlook 2006 with Projections to 2030, U.S. Department of Energy, Washington, D.C., http://www.eia.doe.gov/oiaf/archive/aeo06/index.html, February.

EIA, 2006b, Electricity Market Module of the National Energy Modeling System 2006, DOE/EIA 2006, U.S. Department of Energy, Office of Integrated Analysis and Forecasting, Washington, D.C., March [http://tonto.eia.doe.gov/FTPROOT/modeldoc/m068\%282006\%29.pdf] (accessed February 4, 2010).

EIA, 2006c, Assumptions to the Annual Energy Outlook 2006, U.S. Department of Energy, Washington, D.C., March, http://www.eia.doe.gov/oiaf/archive/aeo06/assumption/index.html.

EIA, 2006d, Annual Electric Generator Report, Form EIA-860, U.S. Department of Energy, Washington, D.C., February, http://www.eia.doe.gov/oss/forms.html.

EIA, 2007, Steam-Electric Plant Operation and Design Report, Form EIA-767, U.S. Department of Energy, Washington, D.C., November 30, http://www.eia.doe.gov/oss/forms.html.

EIA, undated, Monthly Cost and Quality of Fuels for Electric Plants Report, Form EIA-423, U.S. Department of Energy, Washington, D.C., http://www.eia.doe.gov/oss/forms.html.

EIA, undated, Power Plant Report, Form EIA-906,U.S. Department of Energy, Washington, D.C., http://www.eia.doe.gov/oss/forms.html.

FERC (Federal Energy Regulatory Commission), 2006, Annual Electric Balancing Authority Area and Planning Area Report, Form FERC-714, October, http://www.ferc.gov/docs-filing/eforms/form714/overview.asp.

NERC (North American Electric Reliability Corporation), 2009, Generating Availability Data System (GADS), Princeton, New Jersey, http://www.nerc.com/page.php?cid=4|43|47.

NETL (National Energy Technology Laboratory), 2006, Estimating Freshwater Needs to Meet Future Thermoelectric Generation Requirements, DOE/NETL-2006/1235, U.S. Department of Energy, Washington, D.C., August.

NETL, 2007, Estimating Freshwater Needs to Meet Future Thermoelectric Generation Requirements 2007 Update, DOE/NETL-400/2007/1304, U.S. Department of Energy, Washington, D.C., September.

WECC (Western Electricity Coordinating Council), 2006a, Summary of Estimated Loads and Resources, June.

WECC, 2006b, WECC 2006 Power Supply Assessment, http://www.wecc.biz/documents/library/publications/PowerAssessment/2006_Power_Supply_Assessme nt.pdf, May 9. 
This page intentionally blank 



\section{Argonne}

Decision and Information Sciences Division

Argonne National Laboratory

9700 South Cass Avenue, Bldg. 221

Argonne, IL 60439-4844

www.anl.gov 